\title{
Minecraft in Education Benefits Learning and Social Engagement
}

Omar Alawajee, Department of Special Education, College of Sciences and Arts, Qassim University, Ar Rass, Saudi Arabia (iD) https://orcid.org/0000-0003-0540-3629

Jonathan Delafield-Butt, University of Strathclyde, UK

\begin{abstract}
Empirical evidence suggests game-based learning (GBL) as a potentially engaging form of contemporary learning. With the increase in the use of Minecraft, a sandbox computer game in open-world format, there has been a concurrent rise in the level of interest in investigating the role of Minecraft in social and academic learning. Minecraft is socially interactive, and its cooperative, rather than competitive, open-world gameplay suggests that it could be used for educational purposes. This paper presents a systematic review of all published peer-reviewed research and synthesises the evidence for and against Minecraft's use in education to better understand the applicability of Minecraft in educational and psychological interventions. Forty-two papers were identified. These revealed Minecraft to be beneficial in terms of increased motivation, language development, and academic learning in subjects such as science and history. Minecraft play also supported the development of social skills, including communication, sharing, collaboration, and leadership. Concerns about ageappropriateness, safety, technology use, and learning generalisation were raised, but on balance, the evidence favours an informed and guided employment of Minecraft for improved opportunities for learning and engagement in education.
\end{abstract}

\section{KEYWORDS}

Digital Classrooms, Games-Based Learning, Minecraft, Serious Games, Teaching and Learning

\section{INTRODUCTION}

The use of digital games in learning was first adopted in the 1970s, but its widespread use in mainstream classrooms only started in 2007 (Halverson, 2012). Children learn through active engagement with their environment (Baldwin, 1894, 1906; Piaget, 1953, 1962). They test its possibilities and explore its contingencies (Delafield-Butt \& Gangopadhyay, 2013; Trevarthen \& Delafield-Butt, 2014), selfcreating what philosopher A.N. Whitehead (1933) called 'an adventure of ideas'. The engagement of children with other people, ideas or things requires skills that are sensitive to the social situation and the demands of the task, such as self-regulation, awareness, and attention that offer learning in how things proceed (Delafield-Butt, 2018; Trevarthen \& Delafield-Butt, 2015; Tronick, 2007; Eisenberg, Valiente, and Eggum-Wilkens, 2010; Blair, 2002). They create stories or a narrative intelligence of how things are related to each other and highlight their social value. Each child who plays is socially engaged in the adventure of learning (Bruner 2003, Trevarthen \& Delafield-Butt, 2013; DelafieldButt \& Adie, 2016; Whitehead 1929; Donaldson, 1978). These stories give meaning to life's projects and draw attention to understanding the nature of problems within contexts or worlds (Trevarthen \& 
Delafield-Butt, 2013; Bruner, 1990). Within this view, a principal aim of education is to teach learners to think through 'self-directed activity' (Ozmon \& Craver, 2008, p.26). Digital games, with their self-directed play, can help students to become independent thinkers. According to Gee (2013), the purpose of digital games in learning is "to make every learner a proactive, collaborative, reflective, critical, creative, and innovative problem solver; a producer with technology and not just a consumer; and a fully engaged participant and not just a spectator in civic life and the public sphere" (p.1).

Digital games can be used for learning and can be employed for different theoretical approaches, such as through increasing desired behaviours within a trial-and-error approach (behavioural); observing multiple models (social cognitive theory); the process and retrieval of knowledge (information processing theory) and motivating social interaction (intersubjective and social cognition) (Felicia, 2009; Wardlow, 2014). Gee (2017) argues that a game is not limited to fun, but rather that digital games are a "set of well-designed problems to solve" (p.118). A large proportion of digital games are set up with multiple players engaged in the game environment at the same time, providing a form of socialisation where "all sorts of people, institutions, and interest groups get involved and help move meanings in different directions through their talk, arguments, actions, interactions...etc" (p.150). Play contributes to learning and cognitive development and "a child's greatest achievements are possible in play; achievements that will tomorrow become his basic level of real action and morality" (Vygotsky, 1978, p.100). Vygotsky (1986) recommended that learners interact with others, such as peers, teachers and other experts, to help make learning socially meaningful; a notion that stands in agreement with the social intersubjective psychology of learning (Trevarthen and Delafield-Butt, 2013). Learners may then implement what they have learned from one place to another, employing a social tool for problem-solving (Lutz \& Huitt, 2004). Emphasis on social interaction in learning necessitates an enjoyable and fun method for improving social, as well as cognitive, development that gives an emotional and embodied foundation to learned facts because they are lived and shared (Delafield-Butt, 2018).

Learning through digital games may manifest in a similar way to traditional learning, but with more entertainment, enjoyment, and aesthetic appeal. Squire (2011) noted that using digital games in education goes beyond learning to involve a participatory culture and one that encourages systematic thinking and experimentation. Participation is not solely restricted to learning but can create an accessible and safe environment in which to explore and experiment. Three key attributes needs be considered when designing and choosing a game for learning: progression (achievements, levels, and points); feedback (bonuses, countdowns, and reward schedules); and behaviour (infinite gameplay, community collaboration, productivity, and discovery) (Reese, 2011). These elements would provide better educational purposive outcomes, such as teamwork, critical reasoning, and empathy (Janine, 2018).

To conclude, many digital games attract the attention of students and stimulate learning (Kirriemuir \& McFarlane, 2004). Feelings, such as being welcomed into an environment where learning can take place, are a core aspect of education where learners must feel safe and confident in the learning activity. Games that take place in such spaces not only enable students to work towards accomplishing their goals but allow for meaningful feedback and can act as a record to measure the level of learning achieved. Online computer games are mostly interactive; hence, they stimulate learning and motivate learners to challenge new knowledge or topics, and to share these new meanings with others (Felicia, 2011a). Digital games can help students build the skills they may require for living in a society of perpetual technological advancement.

\section{MINECRAFT AS A CREATIVE SPACE FOR PLAYFUL LEARNING}

Minecraft is a colourful sandbox game world rendered in a characteristic three-dimensional blockbuilt environment. Its open, creative gameplay encourages exploration and learning, and indeed requires it (Elliott, 2014). A player moves through the world, interacts with the animals and objects, 
and can begin to build up his or her own constructed environment from the raw materials of the game (Quiring, 2015); for example, stones combined with wood can construct a hammer, a hammer can harvest harder stone, and harder stone can be used to make a strong house. Exploration, testing, and learning about the lawful properties of the unusual Minecraft world are at the heart of the gameplay.

Moreover, Minecraft is social. The lessons learned through trial and error and the creative tools and environments constructed in the Minecraft world can be shared with others in the game, or outside of it (Cipollone, Schifter, \& Moffat, 2014). The Minecraft game is played on a server online, and although one can choose to create a world with no others, it is typically played on servers in worlds with many other players' characters simultaneously exploring, learning, and creating. And within this setting houses can be built, entire cities developed, and empires constructed and shared. There are no restrictions or boundaries and players can play the game as they choose: hunting for animals, building structures, or exploring the landscape and discovering its lawful nature (Elliott, 2014). Clemenson, Henningfield, and Stark, (2019) stated that Minecraft can act as a form of environmental enrichment in humans. Indeed, despite its complexity and depth, Minecraft is recognised as an easy, engaging game with simple, basic rules of operation - move, interact, and combine objects to build new ones (Smolčec \& Smolčec, 2014).

Gauquier and Schneider (2013) note that Minecraft engages considerable critical thinking potential. Players are affected by their choices: if they make 'bad' choices, their avatar's quality of life can be negatively impacted; if they make 'good' choices, the complexity and aesthetics of the game world increase, thereby driving creativity and forming a world shaped by the learner. This sense of creativity with consequences was a principle on which the game was first designed. On the other hand, the avatar aspect allows social interaction without real-world, physical consequence to the player's own vitality, allowing greater freedom from risk for creative exploration (Choo, Karamnejad, \& May, 2013; Mavoa, Carter, \& Gibbs, 2018). It is striking from the perspective of embodiment (Delafield-Butt, 2018; de Jaegher, Perakyla, \& Stevanovic, 2016) that large game-world effects can be generated with simple, small movements of one's own real-world hands and fingers. This is a feature important for consideration for learners with physical disability or motor control issues. And its disembodied aspect can be helpful for those lacking confidence due to risk of social rejection. Further, Minecraft focuses on creativity rather than on winning and competitive gaming. Players are allowed to build whatever they wish using a variety of cubes and colours. For personal use, the game is also affordable, costing approximately $\$ 26.95$ ( $£ 17.95 / € 23.95$ ). Players pay once for ongoing online play with no subscription fees (Mojang Support, n.d.).

The user is free to choose the degree of sociability desired, from closed worlds that can only be accessed by special invitation (useful for classroom learning) to open worlds moderated by peers (such as Autcraft for individuals with autism that has specific rules of social engagement policed by others) to entirely open worlds with few rules of engagement.

The game was launched in 2010, developed by Markus Persson who became a popular legend within the game world known by his avatar, Notch. Minecraft can be played on a Windows PC or Apple computer and most modern smart mobile devices, namely Android or iOS tablets and phones. The game has been running continuously since its launch and has generated a userbase that now spans the entire globe. At the end of June 2019, more than 33 million people had bought the computer version of Minecraft (Minecraft, n.d.). There are also specialist versions of Minecraft that serve different user communities. For example, Autcraft is a particular platform of Minecraft for people with Autism Spectrum Disorder (ASD), founded in 2013 by Stuart Duncan who himself is on the autism spectrum and who has a child with ASD. Indeed, almost anyone can play the game, regardless of ability, gender, culture, or background, although it is officially categorised as suitable for children nine years old or over (iTunes, n.d.), the Pan-European Game Information (PEGI) system rated Minecraft as appropriate for seven years or older (PEGI, 2016), and younger children may also benefit from the game. Age considerations are highlighted in the discussion section below. 
Players appear to like Minecraft because it allows them to modify the game (Tong, 2011). Newzoo. com (2014) analysed hundreds of the most popular computer games over multiple variables in six developed countries - the United States, the United Kingdom, France, Germany, Belgium and the Netherlands - and found that over 36 million of the players in these countries ranged between ten and fifty years old. Minecraft was ranked ninth in terms of popularity. This research also reported that about $33 \%$ of Minecraft players were female and $81 \%$ of players played at home for more than half of their gaming time. Approximately $36 \%$ of the participants in this dataset had been playing the game for more than a year, and $24 \%$ had played the game for six months or more, but less than a year (Newzoo.com, 2014).

\section{STATE OF KNOWLEDGE ON MINECRAFT AND EDUCATION}

However, despite its popularity, for educational purposes there is limited information about the effect of using Minecraft within learning (Sáez-López et al., 2015). Moreover, there are different opinions regarding the general use of computer games. Some fear that such games may render children more passive and isolated (Wernholm \& Vigmo, 2015; Willett, 2015). These arguments are explored in the discussion section of this review. Minecraft was not explicitly designed for educational purposes (Willett, 2015), but as the game has no limits and allows users to construct a world and share it with others, it quickly found a place within some classrooms. Significantly, a specialist Minecraft Education Edition was launched in 2014 as a platform specifically tailored for its educational use. It is custombuilt worlds makes it attractive for use in teaching topic such as Ecology, Biology, Chemistry, Physics, Geology, and Geography, as well as mathematical concepts and rules (Short, 2012). In fact, a group of pre-service training teachers found Minecraft to be useful for teaching any subject (McColgan, Colesante, \& Andrade, 2018.)

Using new media to form an engaging curriculum provides students with a responsibility to direct their learning and achieve their own goals (Elliott, 2014), while also fostering their independent learning. It is essential to allow children to follow their interests in the classroom to benefit motivation for learning (Gunn \& Delafield-Butt, 2016), and Minecraft can facilitate this in its open-world, child-led format. Minecraft Education Edition has many mods, curriculums and exercises to meet the Common Core State Standards and the Next Generation Science Standards, which are relevant to the US curriculum (Teaching with MinecraftEdu, n.d.). Therefore, Minecraft seems to be a promising educational tool: it merges the conceptual ideas of collaborative learning with a serious game, especially in the multiplayer version (Wendel et al., 2013). Many studies have suggested the development of games for educational purposes and implementing the game-based learning concept to encourage student engagement (Boyle, Connolly, Hainey, \& Boyle, 2012); this could be done by following their interests (Gunn \& Delafield-Butt, 2016). Many researchers suggest Minecraft could be an advantageous educational tool in that it supports and encourages cooperative learning more than games that tend to focus on competitive learning (Al-Washmi et al., 2014; Quiring, 2015).

\section{RESEARCH AIMS}

Researchers, educators, and parents may debate what makes it so appealing and whether there is any intellectual or social value in such gameplay. There have been previous systematic reviews on computer games and serious games (Connolly et al., 2012; Grossard et al., 2017), Game-Based Learning (Abdul Jabbar \& Felicia, 2015), and digital or computer games (Boyle et al., 2012; Clark et al., 2015; Tobias \& Fletcher 2012; Mekler et al., 2014), but they did not focus on Minecraft. Hence, the question of this review paper is whether Minecraft has any impact on children's social and academic learning. We define social learning as learning social skills, such as cooperation, self-control, confidence, independence, curiosity, empathy, and communication. And we define academic learning as all learning that pertains to the educational curriculum, all subjects such as reading, writing, maths, 
history, biology, and so on. Therefore, this article aims to examine all contemporary research on the use of Minecraft in an educational setting in order to summarize and synthesise current literature with its available evidence to find whether Minecraft can be efficiently and beneficially utilised in the classroom, or not. Reviewing the use of Minecraft in an educational setting is significant in demonstrating its advantages and disadvantages for further classroom implementation and learning interventions. This review will develop researchers' current understanding of using the game as an educational tool or an instructional psychology one and will summarize the reported benefits and limitations. The EBSCOHost research website produced a large number of results from newspapers and magazine articles, without a single systematic review of Minecraft, and there is currently no literature review that examines whether Minecraft is a useful teaching tool or what practical limitations might be avoided in future classroom execution. Thus, this review examined all available and identified research on Minecraft used as a method of teaching or developing students' skills in the classroom, and its benefits or drawbacks.

\section{METHOD}

This review was conducted on a broad literature search designed to identify and review all available peer-reviewed journal articles reporting on empirical studies on the use of Minecraft up to the 17th of September 2019. We have included all articles that encompassed primary data sources for the use of Minecraft/Autcraft, including psychological and sociological studies. Autcraft was included alongside Minecraft as a common platform important for specialist and inclusive educational contexts. This specific focus on peer-reviewed literature affords the most reliable data on the effects of Minecraft in teaching and learning with the acknowledgement of possible publication bias. However, since both the negative and positive effects of Minecraft are equally important and publishable, selection bias in one direction or the other is unlikely. Thus, this review provides the best possible presentation of both positive and negative effects of Minecraft in educational contexts.

This review went through five stages: identifying the research problems; screening relevant work; discussing inclusion criteria and negotiating eligibility; summarizing evidence from included studies and interpreting the findings. The eligibility process was conducted by the two authors and then compared, disagreements discussed, and an agreement achieved for each paper based on meeting the inclusion criteria (stated below). The methodology of the review used the Preferred Reporting Items for Systematic Reviews and Meta-Analyses (PRISMA) (Moher, Tetzlaff, \& Altman, 2009). PRISMA is an evidence-based set of checklists and procedures for conducting and reporting in systematic reviews and meta-analyses. The PRISMA framework was used initially for reporting reviews and evaluating randomised trials but has also been used for reporting systematic reviews of other types of research. In this review, we used the PRISMA checklist and PRISMA 2009 Flow Diagram to help develop appropriate review processes.

For this review, we conducted a literature search on $17^{\text {th }}$ September 2019 using EBSCOHost research website, which carries a wide range of academic research databases. Our research term was only "Minecraft" or "Autcraft". EBSCOHost research website was used, producing a significant number of academic resources and journal articles. In relation to identifying related databases, eleven academic and psychological were selected, as following databases: British Education Index, Child Development \& Adolescent Studies, Education Abstracts (H.W. Wilson), ERIC, Library, Information Science \& Technology Abstracts, PsycARTICLES, PsycBOOKS, PsycINFO, Communication \& Mass Media Complete, OmniFile Full Text Select (H.W. Wilson), and Teacher Reference Center.

We found 480 results, limited to 267 after removing exact duplicates between databases. We restricted this to 89 papers that were peer-reviewed for journals. This was further reduced to 85 papers written in English. After that, an examination and selection process was carried out following the PRISMA framework (Figure 1), which demonstrates the screening process. Papers were included if they met all the following criteria: 
Figure 1. Flow diagram of the screening and selection process employed to search and select the articles reviewed

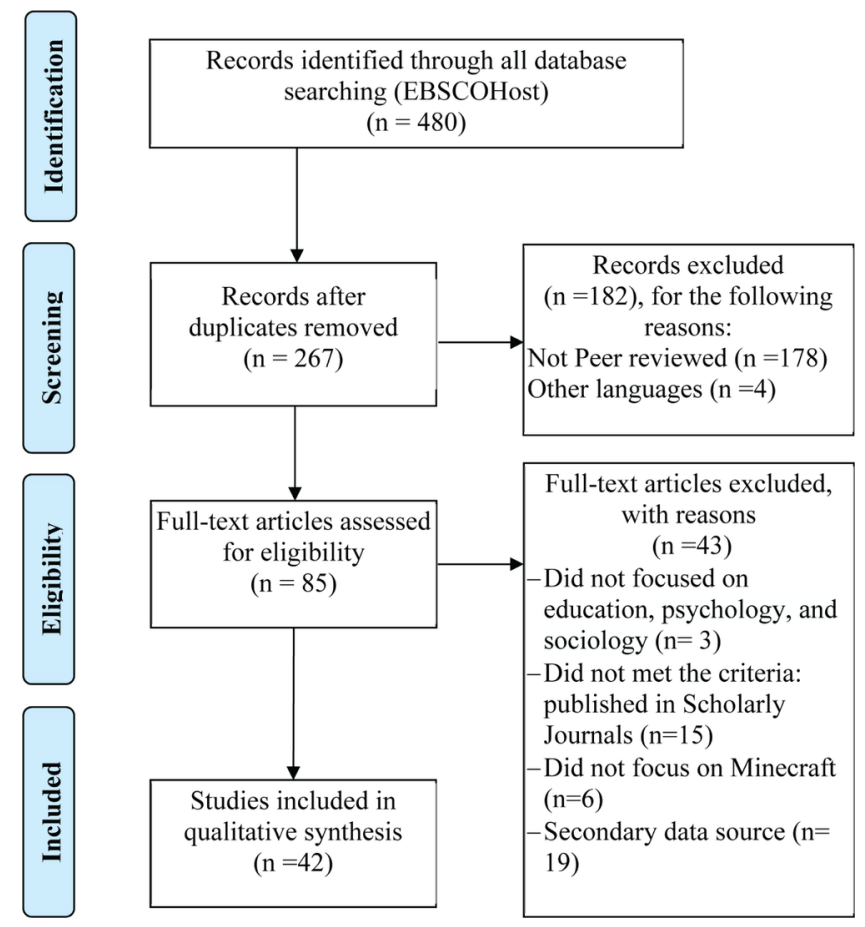

- The study had to have been published in scholarly (peer-reviewed) journals to meet a minimum standard of quality and reliability from other scholars' view (book reviews, conference abstracts, proceedings papers, newspaper articles, magazine articles, and media reports were excluded).

- This review includes only studies that focused on the educational, psychological, and sociological use of Minecraft.

- The publications had to be empirical examinations of the use of Minecraft. Thus, all secondary sources were excluded.

- The articles needed to be in English.

The following PRISMA (2009) Flow Diagram explains how the criteria worked through the databases' websites.

The eligible papers $(n=42)$ were coded and analysed using a data extraction tables that included the research aspects and outcomes (Table 1 and Table 2). The characteristics correlated to the included papers were coded including (a) research aim or purpose, (b) research design (e.g., the intervention, research setting, etc.), (c) research sample (size of the sample and age), (d) data collection approach (e.g., survey, interviews, experiment, etc.), and the key findings. After that, the quality of the included paper was assessed and scored according to the Connolly, Boyle, MacArthur, Hainey, and Boyle (2012) scale (Figure 2). The Connolly et al. (2012) scale focuses on the following five criteria: the type of research, the study's appropriateness of the method and analysis, generalisability (size and representativeness of the sample), the study's importance to this review, and confidence in the presented results. Each one of the previous criteria received a rate as following $(3=$ high; $2=$ medium; $1=$ low) and a total score (maximum $=15$ ). The key findings section (Table 1 and Table 2) presented in the results section of this review was conducted using thematic analysis and synthesis of qualitative research in systematic reviews. The thematic analysis was divided into six phases according to Marshall and Rossman (1999): organising the data, generating themes, coding the data, testing understanding of the data, searching for alternative explanations of the data, and writing up the data analysis. 
Figure 2. Histogram of the weight of evidence quality score for all included papers

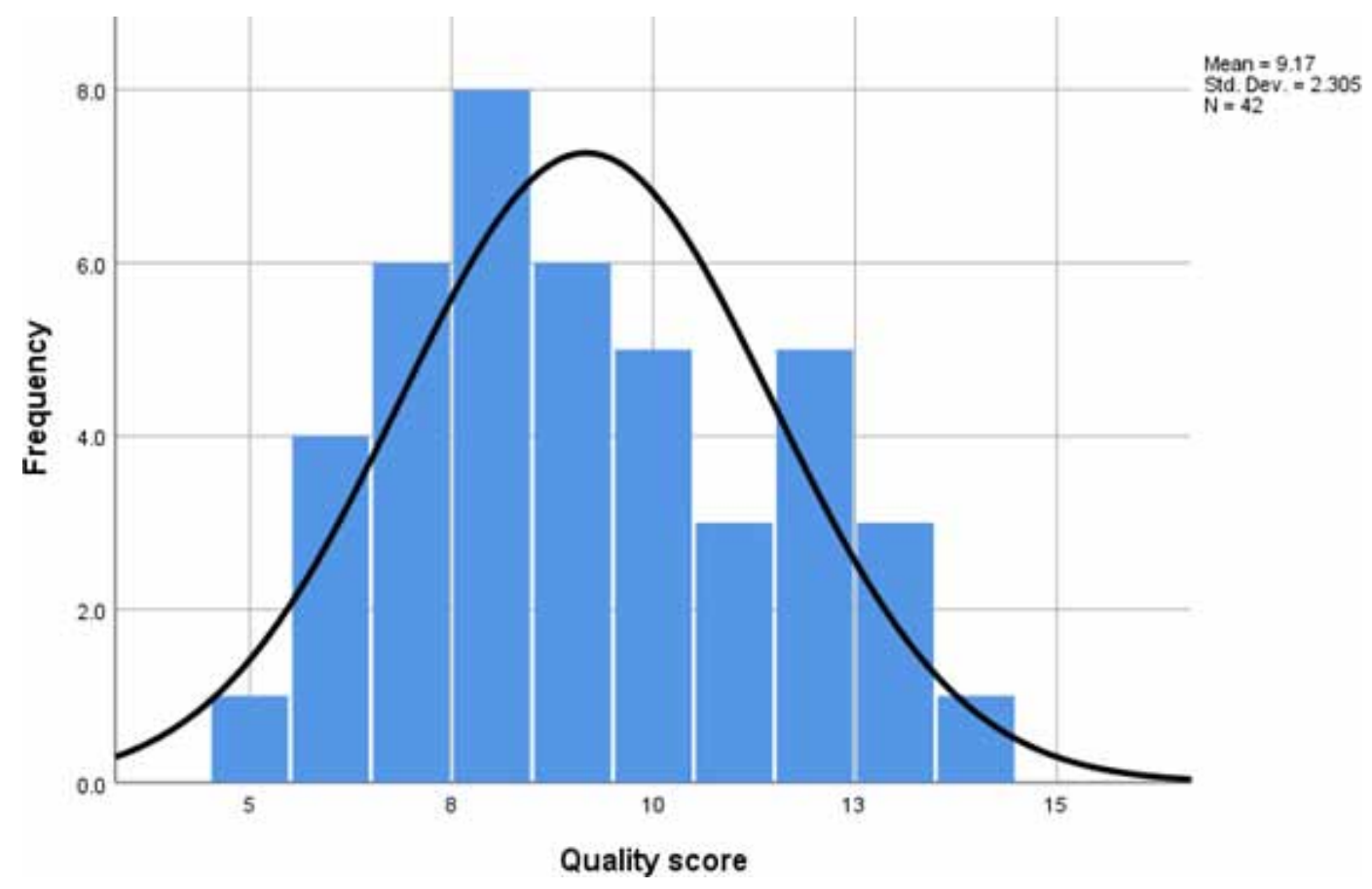

\section{RESULTS}

Studies included in this review showed a variety of employed methods. Eight studies (19\%) used quantitative approaches, 23 studies (55\%) used qualitative methods, and 10 (26\%) used a mixedmethods approach. Although 27 studies (64\%) included an educational, psychological, or sociological intervention in the investigations, only $8(19 \%)$ included a control group. The age of the samples was also different: eight studies (19\%) included children aged 10 or less, $15(36 \%)$ included teenagers aged $11-17,14$ studies (33\%) included adults aged 18 and over, and five studies (12\%) were indefinable due to poor clarity within the research designs presented. In terms of sample size, more than half of the studies used 1-16 participants (23 studies; 55\%), whereas five (12\%) and eight (19\%) studies had a sample size of 17-64 and 65-205 participants, respectively. Three studies (7\%) had a sample size of 322 and 394 participants, and another three studies (7\%) did not use a sample. As shows in Figure 2, each of the included papers was given a quality score, the mean rating for the 42 papers was 9.2 on Connolly et al.'s (2012) scale. Since the number of included papers was small all papers were discussed regardless of the quality score, but emphasis was placed on papers rated 9 or above as they were considered to provide a stronger evidence base for or against the use of Minecraft in academic and social learning. Furthermore, Figure 3 shows an increasing number of publications over the years, showing the importance of this topic in social and academic learning. Figure 4 explains the methodological choices for the studies included, as explained previously.

Most of the included articles illustrate how Minecraft can be a useful tool for educational use, and social and communication learning if it was used effectively with well-designed lesson. These are presented in Table 1 and Table 2, respectively. Given that there are only a small number of eligible papers, all 42 are summarized in these tables and discussed. In the following sections, the articles are reviewed based on the skills that are impacted by the research. 
International Journal of Game-Based Learning

Volume $11 \cdot$ Issue $4 \cdot$ October-December 2021

Figure 3. Number of publications selected for review according to the year of publication

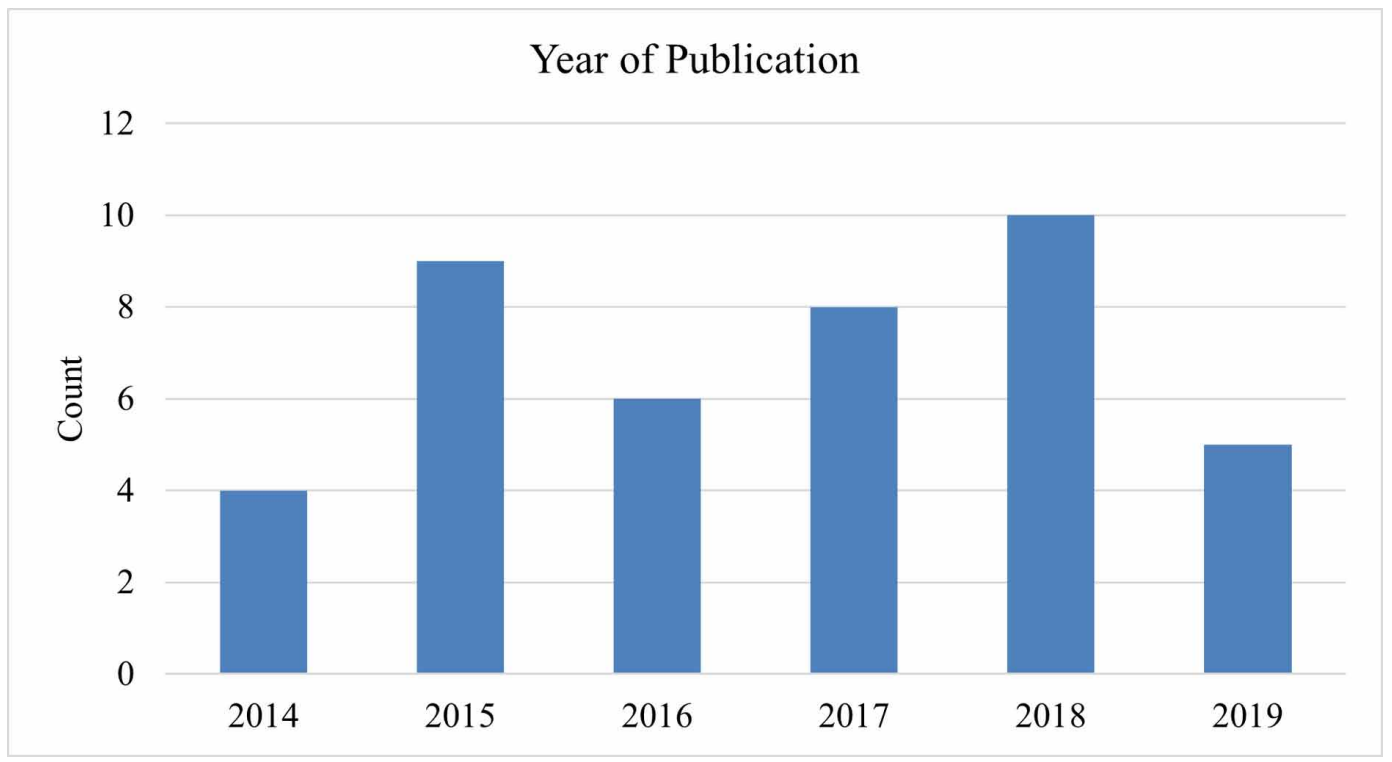

\section{MINECRAFT CAN INCREASE MOTIVATION FOR LEARNING}

Minecraft is thought to be a useful tool for increasing students' motivation and interest in their learning environment. In fact, the game attitudes significantly predicted intrinsic motivation, which can be a significant predictor of game enjoyment, where players with a basic motivation experienced higher levels of enjoyment in the game (Baek \& Touati, 2017); and for academic learning, games need to be

Figure 4. Methodological choices for studies reviewed, including participant group characteristics

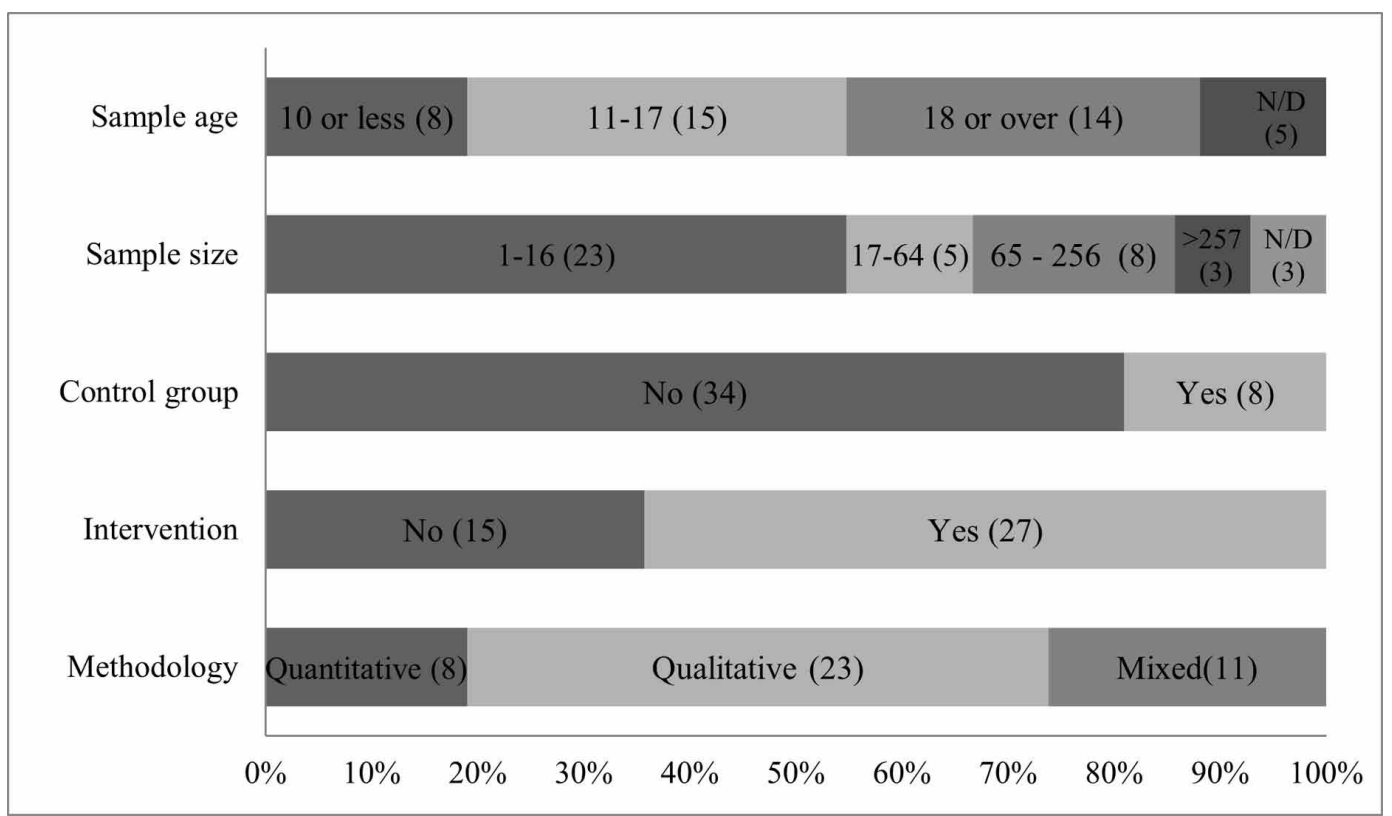


enjoyable to be effective. Although the ability to enjoying was not defined in the reviewed studies, there is a tendency to be defined by having a positive attitude about the Minecraft experiment and the learned content. Nebel et al. (2017a) reported that student' reactions to Minecraft experiment were pleasant and researchers received only positive feedback from students about the experiment because using Minecraft allowed the transfer of educational principles to a new pedagogical medium, with Minecraft offering players more opportunities for creativity. A positive attitude is essential for learning; the goal was not only learning to read but to engage students and create a positive, inspiring environment (Nebel et al., 2017a).

Although having specific learning goals lowered extraneous and intrinsic cognitive load, players reported more fun and effective impacts of goal-setting and deeper motivational processes (Nebel, Schneider, Schledjewski, \& Rey, 2017b). However, many participants working within a group with defined goals exhibited anger, impatience, or confusion when it was clear they would not be able to reach their goal, which may be deemed a disappointing element of the game. In contrast, participants active in the goal-free environment started the game by reading the information and trying to solve the tasks (Nebel et al., 2017b). This is clearly a limitation to the implementation and preparation for the Minecraft study and not a limitation of Minecraft; having a specific learning goal with a defined task would contribute to the children's learning and reduce wasted classroom time.

Minecraft can also be considered a useful method for promoting student engagement in school and the community. Many researchers identified clear engagement advantages for students as a benefit of using Minecraft. For example, Cilauro's study (2015) reported that using Minecraft allowed disadvantaged young people to be socially included and involved in the online game, as well as to participate socially with others from different cultural backgrounds (Cilauro, 2015). Hollett \& Ehret (2017) concluded that Minecraft helped teenagers to engage outside the school context through a shared interest in the game. Another example was reported by Elliott (2014) who reported that prior the Minecraft experiment, one student had poor school attendance and struggled within a formal learning space and tended to refuse to accomplish assignments and disengaged from his schoolwork. However, after the Minecraft intervention, the student displayed remarkable changes, with the teacher reporting that he had not only become more confident with his peers but that Minecraft had rekindled his interest in school and he had begun to attend class regularly, with a more positive attitude (Elliott, 2014). Furthermore, MacCormack \& Freeman (2019) reported that although a low degree of motivation of youth with ASD to interact with others was observed during the free play in the early sessions, structured play increases the quality of social play and players were more engaged as they participate in shared goals as they had to make and respond to social bids, suggesting that Minecraft may be a useful modality for motivating youth with ASD to learn and practice social skills. Stone, Mills, and Saggers (2019) investigated whether Minecraft can be used for social interaction for three children with ASD and reported that playing Minecraft with others provides opportunities for social and communication interactions in multimodal ways that are not available in face-to-face and offline contexts, which promote children's with ASD ability to initiate and sustain social interactions in inclusive educational settings.

Furthermore, Ellison (2017) reported that a participant from a minority group chose to create a digital story using Minecraft, illustrating the intended literacies and racial identities, inherent in digital participatory choice cultures. The decision to use Minecraft meant he was able to plan and map the story from beginning to end, creatively and independently, and felt comfortable operating within Minecraft. He reported that 'he was afforded opportunities to make decisions and became a problem solver and critical thinker while creating and exploring Minecraft worlds' (p.31). The study enabled researchers to understand how the race was essential to the participant, clearly evidenced in his digital story, where he was able to build on his knowledge and identity.

Although Minecraft could be considered as a great engaging tool because even those with no experience of the game can engage with it easily, Marcon and Faulkner (2016) stated that participants with no experience of the game had some difficulties. Cilauro (2015) reported similar issues when 
a number of young people were either not able to fully participate in the activity or were not able to be part of the group dialogue, which led to some isolation. Potentially, this is a disadvantage because all educational tools should engage all students in the activity. On the other hand, children in Petry's (2018) study emphasised that the freedom of being able to create whatever they wanted - the 'open space' idea-was the main reason to continue playing Minecraft. Likewise, Checa-Romero and Pascual Gómez, (2018) and Blanco-Herrera, Gentile and Rokkum, (2019) concluded that using Minecraft, with its high level of freedom, in an educational subject led to an increase in students' creativity and engagement with the classmates.

\section{ACADEMIC LEARNING WITH MINECRAFT}

Minecraft is a tool that can be used for educational purposes. McColgan, Colesante, and Andrade (2018) examine the pre-service teachers' skills, beliefs, and confidence using Minecraft to create lessons for teaching middle and high school students and reported that most of the participants decided to create lessons in STEM topics, "such as physics, math, earth science, anatomy, and others" (p. 20). . The experiment results show that the mean scores were higher at the post-test than the pre-test for perceptions of skill using technology and confidence with new technologies, with no gender differences. Participants reported three themes of positive changes in the classroom and their beliefs of using Minecraft emerged, which are the acquisition of knowledge/skills; engagement; and collaborative interaction. Therefore, teachers and parents have begun to adopt it as a tool to enhance and develop children's academic skills and facilitate learning. For example, Saito, Washizaki, and Fukazawa (2017) reported that participants' attitudes toward programming improved and participants' interest in programming increased (Saito et al., 2017). In addition, students in Callaghan's study (2016) reported that they felt that MinecraftEdu helped them attain their learning goals and played an important role in creating a specific task and accomplishing the desired outcomes; in fact, all students demonstrated a higher level of 'creative' and 'evaluative' skills (Bloom's Taxonomy). Being creative in learning is an important aspect of today's pedagogy (Ejsing-Duun \& Skovbjerg, 2016; Mason, 2017). Checa-Romero and Pascual Gómez, (2018) examined empirical evidence of creativity development using Minecraft in the classroom and reported that a significant increase in creativity was founded, highlighting the needs to be used in classrooms to develop innovative educational contexts. Another study conducted by Moffat, Crombie, and Shabalina (2017) Moffat et al. (2017) testing the impact of three games (puzzle, sandbox, or a first-person shooter) on creativity using Torrance Tests of Creative Thinking, which measures divergent thinking. Researchers reported that sandbox games affected creativity less than other types of games, such as a puzzle or first-person shooter game. Flexibility, as a form of creativity, was affected much more compared to fluency and originality where players exhibited little or no observable changes in their ideas; and with the limitation of this study's results, computer games could be used to engage students in a more creative state of mind, necessary for their learning (Moffat et al., 2017). Similarly, Blanco-Herrera, Gentile and Rokkum, (2019) reported that playing Minecraft in the undirected condition scored higher in the fluency category of AUT and performed better on the ADT than participants in the other conditions, suggesting that undirected Minecraft condition provided opportunities for creative thought and expression that is beneficial for the creativity effects (as they may had a lot of decisions and problems to solve). Therefore, both Blanco-Herrera et al. (2019) and Moffat et al. (2017) concluded that computer games seem to have a temporary effect on creativity, but this effect differs based on the game type.

Minecraft can be used to encourage students to become skilled in creating narrative scenarios by using language proficiency to optimise scenarios. Cipollone et al. (2014) used the game as a tool to explore literary concepts of scenarios created by one English teacher to explore the concepts of characterization, where "the desired outcome of this assignment was a video of the narrative, or machinima, developed by each group to demonstrate their understanding of the literary concepts" (p.5). The researchers reported that three groups out of five were able to create narratives using 
Minecraft and developed multiple characters with a range of personality traits, and Minecraft gave students access to a creative space, with less cost, to explore different narratives with a meaningful and useful interaction between students and the content. Marlatt (2018b), moreover, examined students' engagement in literary analysis of a novel and reported that the Minecraft motivated the participant to engage with the text and was a vehicle for his during-reading visualization and offered students with opportunities to cultivate multicultural perspectives. Marlatt (2018a) also reported that Minecraft help learners to crafted well scenes that linked to the reading of the text, showing detailed and sustained engagement well with literature.

Furthermore, teaching first or second languages can be aided by using Minecraft as a mediator between players and the academic content with well-designed lesson, as it increases the learner's desire to engage. Marcon and Faulkner (2016) examines the use of "Minecraft" to motivate girls' literacy practices in a secondary English classroom through certain actions within the game to motivate students' discussion and collaboration of planning and building. Researchers reported that Minecraft was an attractive text for literacy learning and helped participants to work collaboratively and strategically in designing and immersing themselves in the game world, as well as allowing them to use problem-solving skills for distributed learning initiatives. However, playing Minecraft in the classroom was not confined to participants who had played before or had experience of the game, as reported previously, but offered players an opportunity for learning, allowing players to engage with others around them, and participants used expressive language to obtain assistance from other players and provided meaning for their actions, which resulted in an engaging, collaborative environment. They expressed their interest in gaming activities in their online social media platforms, indicating further learning beyond the classroom. They exhibited problem-solving skills and positive achievements during gameplay (Marcon \& Faulkner, 2016). In addition, another study concluded that "playing the video game Minecraft can positively impact hippocampal function in the form of improved memory performance on tasks unrelated to activities in the game itself" (Clemenson, Henningfield, \& Stark, 2019, p.11). Therefore, there was robust evidence that the games provided social and cognitive opportunities for creating and strategizing while playing.

Moreover, Minecraft was utilised as a tool to practice and engage with second language skills. Smolčec and Smolčec (2014) reported that Minecraft helped their son to learn and develop his English and speaking skills because he communicated with native speakers through Minecraft and improved his listening skills by watching and listening to Minecraft videos on YouTube, resulted on becoming 'skilfully creative and speak English with an American accent' (p.13). Another study was undertaken to consider goal-orientated communicative tasks for virtual worlds adopting Minecraft (Swier, 2014). Researchers reported that Minecraft seemed to be a useful platform for developing tasks for language learners, and negotiation was clearly observable in the completion of the three tasks, meeting the intended goals. All participants indicated that they enjoyed the session and were able to manage the completion of assigned tasks in roughly the same amount of time. Participants reported that their communicative interaction during the tasks could improve their English, with the opportunity to speak English and work together (Swier, 2014). Furthermore, Minecraft was used in teaching English to international students by Egbert and Borysenko (2019) and they reported that Minecraft prompted discussion and speaking skills; indeed, about $73 \%$ of the pre- and in-service language teacher education students said that they would definitely use Minecraft in their future language teaching. Hence, Minecraft was able to improve their language skills through social interaction with other players. Sáez-López et al. (2015) found similar second language improvements in their study. Participants were asked to engage in Edmodo, a platform discussion where players, teachers, and parents interact and communicate with each other between the US and Spain. Researchers found that foreign students interacted with each other in English, although they were Spanish, which reflected the advantages of using Minecraft as a tool for practising communication and second language skills. Thus, despite Minecraft not being explicitly designed to improve language skills, it can assist players in practising in this field. 
Minecraft might also be used for teaching history and architecture. Sáez-López et al.'s (2015) stated that the results illustrated that $97.1 \%$ of participants in the experimental group (who studied a historical event via an immersive environment in MinecraftEdu) believed that the game encouraged them to learn about historical content, although the results of the academic unit testing did not show a significant difference between the control group and the experimental group. Furthermore, Craft (2016) reported that although some students were able to complete the task (given within the Minecraft world) before the deadline, many did not; nonetheless, the implication of this project was largely successful, with evidence of success presented in the pre- and post-written assessments on student understanding of Roman architecture. The growth of students' scores from pre- to post-assessment ranged from $20 \%$ to $38 \%$; the average growth score was 29\% (Craft 2016, p.360). Therefore, Minecraft can facilitate some students learning historical topics.

\section{LEARNING SOCIAL SKILLS IN MINECRAFT}

The previous section provided a presentation about the use of Minecraft for academic learning, with most studies highlighting that it was useful for academic and social learning if used effectively. Schneier and Taylor (2018) observed that players engaged with each other in the play sessions and healthy social and emotional interactions were observed. Minecraft, indeed, helped children with ASD to engage in reciprocal conversations, attracting others' attention, and engaging with others physical and in the virtual worlds, which is important to fulfil their needs (MacCormack \& Freeman, 2019; Stone et al., 2019). Similarly, Through Minecraft, children demonstrated an understanding of literacy potential for impacting families and society, showing critical awareness of social inequality and prejudice in sociocultural interaction (Marlatt, 2018a). In addition, Hook, Baxter, and Kulczynski (2016) indicated that children with high evaluative social identities experienced positive feelings and emotions when they were able to interact with the brand-based social network and felt negative emotions when they were prevented from connecting with others.

Callaghan (2016), furthermore, stated that the teacher reported that the players of Minecraft in the study intervention were collaborative in sharing expertise, creating objects, solving problems, or completing a build; the more students vocalised, the more productive they became. The teacher also reported that her relationships with students had strengthened as a result of being online with them (Callaghan, 2016). Moreover, Nebel, Schneider, and Rey (2016) showed that lowered focused attention, significant higher cognitive load, extraneous and intrinsic cognitive load increased induced by social competition, and an increase in learning in the solo condition was observed. An extraneous cognitive load was reported by the players in the social competition because of the increased effort in working within a group environment. An increased intrinsic load for the classroom social competition was observed compared to solo play, which might be plausible due to given intrinsic load, as it is influenced by the interaction of the learning material (Nebel et al., 2016). However, no differences in satisfaction were observed, which might be because not every participant appeared to be challenged with an equally skilled competitor or the learning topic was not challenging (Nebel et al., 2016). Interestingly, the results of the group variation highlighted that monitoring other players caused adverse effects, and players in the competitive scenarios learned significantly less from their environment (Nebel et al., 2016). When the number of competitors is higher, some elements of engagement were decreased because they can distract each other, but higher challenges were positively related to a better level of engagement (Nebel et al., 2016).

Despite that improving social skills might not be the aim of researching Minecraft, their enhancement can be a positive outcome. For example, although players have reported that YouTube and books are the primary resources for obtaining ideas about how to play and be creative, all the participants indicated that Minecraft helped them to collaborate with others, engage in discussions, and share knowledge of the game with friends, contributing to developing social skills between players (Petry, 2018). Indeed, 37\% of children watch YouTube related to Minecraft (Mavoa et al., 
International Journal of Game-Based Learning

Volume 11 •Issue 4 • October-December 2021

Table 1. Summary of all included studies about Minecraft (MC) focuses on academic and motivation to learning outcomes

\begin{tabular}{|c|c|c|c|c|c|c|}
\hline \multirow{2}{*}{$\begin{array}{l}\text { Author/ } \\
\text { citation }\end{array}$} & \multirow[t]{2}{*}{ Study aim } & \multirow{2}{*}{$\begin{array}{l}\text { Research design } \\
\text { (intervention) }\end{array}$} & \multirow{2}{*}{$\begin{array}{l}\text { Sample } \\
\mathrm{N} \text { (Age) } \\
\end{array}$} & \multirow{2}{*}{$\begin{array}{l}\text { Data collection } \\
\text { approach }\end{array}$} & \multirow[t]{2}{*}{ Key findings } & \multirow{2}{*}{$\begin{array}{l}\text { Connolly et al. } \\
\text { scale score }\end{array}$} \\
\hline & & & & & & \\
\hline $\begin{array}{l}\text { Baek and Touati } \\
\text { (2017) }\end{array}$ & $\begin{array}{l}\text { Testing } \\
\text { relationships } \\
\text { between enjoyment } \\
\text { \& learning styles, } \\
\text { collaboration } \\
\text { skills, intrinsic } \\
\text { motivation, } \\
\text { game attitude, } \\
\text { \&achievement. }\end{array}$ & $\begin{array}{l}\text { Participants were given } \\
\text { two tasks for their } \\
\text { gameplay: 1) choosing } \\
\text { and replicating a maze } \\
\text { in MC from three } \\
\text { levels of difficulty; } \\
\text { 2) building the main } \\
\text { school building and } \\
\text { playground in MC. }\end{array}$ & $\begin{array}{l}164(11- \\
12)\end{array}$ & $\begin{array}{l}\text { Students were given: } \\
\text { the Computer Game } \\
\text { Attitude Scale, } \\
\text { Enjoyment Test, } \\
\text { Learning Style } \\
\text { Inventory, Computer } \\
\text { Game Attitude } \\
\text { Scale, Collaboration } \\
\text { Attitude Test, \& } \\
\text { Intrinsic Motivation } \\
\text { Inventory. }\end{array}$ & $\begin{array}{l}\text { - Players with more } \\
\text { intrinsic motivation } \\
\text { experienced higher } \\
\text { levels of enjoyment that } \\
\text { significantly correlated } \\
\text { with achievement. } \\
\text { - MC as an educational } \\
\text { tool can motivate } \\
\text { students intrinsically, } \\
\text { regardless of extrinsic } \\
\text { roles in driving students' } \\
\text { behaviours. } \\
\text { - Players with a } \\
\text { more positive attitude } \\
\text { toward the game were } \\
\text { intrinsically motivated } \\
\text { to play it. } \\
\text { - Students exhibiting } \\
\text { more positive } \\
\text { collaboration skills were } \\
\text { more able to perform in } \\
\text { gaming achievements. }\end{array}$ & 11 \\
\hline $\begin{array}{l}\text { Blanco-Herrera, } \\
\text { Gentile \& } \\
\text { Rokkum, (2019) }\end{array}$ & $\begin{array}{l}\text { To find whether } \\
\text { playing Minecraft } \\
\text { can benefit players' } \\
\text { performance on } \\
\text { creativity measures }\end{array}$ & $\begin{array}{l}\text { Participants were } \\
\text { randomly assigned } \\
\text { to one of four groups } \\
\text { for approximately } 45 \\
\text { min: undirected play } \\
\text { on MC; directed MC } \\
\text { (participants were } \\
\text { directed to 'play as } \\
\text { creatively as they } \\
\text { could'; NASCAR (a car } \\
\text { racing game), and TV } \\
\text { (watched an episode, } \\
\text { called Crocodile } \\
\text { Hunter). }\end{array}$ & $\begin{array}{l}352 \text { (Avg. } \\
19.33)\end{array}$ & $\begin{array}{l}\text { Researchers used } \\
\text { the video game } \\
\text { history questionnaire } \\
\text { (VGHQ) and } \\
\text { four measures } \\
\text { of creativity: the } \\
\text { Divergent thinking: } \\
\text { alternative uses task } \\
\text { (AUT), Convergent } \\
\text { thinking: remote } \\
\text { association test } \\
\text { (RAT), imaginative } \\
\text { capability scale } \\
\text { (ICS), and Creative } \\
\text { production: alien } \\
\text { drawing task (ADT). }\end{array}$ & $\begin{array}{l}\text { - In the VGHQ, } 89.8 \% \\
\text { of the participants } \\
\text { reported playing a } \\
\text { video game in the last } 6 \\
\text { months. } \\
\text { - The grades were } \\
\text { associated with most } \\
\text { measures of creativity, } \\
\text { but no significant } \\
\text { association between } \\
\text { parental income, age, or } \\
\text { gender and any of the } \\
\text { creativity measures. } \\
\text { - Game-playing habits } \\
\text { associated negatively } \\
\text { with school performance } \\
\text { (GPA) but correlated } \\
\text { positively with trait } \\
\text { creativity. A positive } \\
\text { correlation was observed } \\
\text { between self-reported } \\
\text { gameplay exposure and } \\
\text { trait creativity } \\
\text { • Participants in the } \\
\text { undirected Minecraft } \\
\text { condition scored higher } \\
\text { in the fluency category } \\
\text { of AUT than the } \\
\text { NASCAR condition, and } \\
\text { performed better on the } \\
\text { ADT than participants } \\
\text { in the other conditions, } \\
\text { suggesting that } \\
\text { undirected Minecraft } \\
\text { condition provided } \\
\text { opportunities for creative } \\
\text { thought and expression } \\
\text { that is beneficial for } \\
\text { the creativity effects } \\
\text { (as they may had a } \\
\text { lot of decisions and } \\
\text { problems to solve) rather } \\
\text { than being directed to } \\
\text { specific tasks which may } \\
\text { limit being creative. } \\
\text { isteing }\end{array}$ & 14 \\
\hline Butler (2017) & $\begin{array}{l}\text { Examining the } \\
\text { semantic properties } \\
\text { of spontaneous } \\
\text { naming systems } \\
\text { and potential } \\
\text { influence. }\end{array}$ & $\begin{array}{l}\text { Participants explored } \\
\text { a closed environment } \\
\text { in MC to locate } \\
\text { an assigned goal, } \\
\text { verbalizing their } \\
\text { ongoing thoughts. }\end{array}$ & $12(16-26)$ & $\begin{array}{l}\text { Data were collected } \\
\text { through observing } \\
\text { participants for } \\
\text { considered proper } \\
\text { nouns while the task } \\
\text { was carried out for } \\
\text { the twelve runs. }\end{array}$ & $\begin{array}{l}\text { - Names do serve } \\
\text { a functional role in } \\
\text { providing cognitive } \\
\text { navigational assistance. } \\
\text { Functional identificatory } \\
\text { semantics was consistent } \\
\text { although the nature } \\
\text { of the participatory } \\
\text { group was limited. } \\
\text { A significant strong } \\
\text { negative correlation } \\
\text { (-0.88) between } \\
\text { numbers of names } \\
\text { generated and speed } \\
\text { of task completion, so } \\
\text { cognitive mapping is } \\
\text { highly impacted by the } \\
\text { name development. }\end{array}$ & 7 \\
\hline
\end{tabular}


International Journal of Game-Based Learning

Volume 11 •Issue 4 • October-December 2021

Table 1. Continued

\begin{tabular}{|c|c|c|c|c|c|c|}
\hline \multirow{2}{*}{$\begin{array}{l}\text { Author/ } \\
\text { citation }\end{array}$} & \multirow[t]{2}{*}{ Study aim } & \multirow{2}{*}{$\begin{array}{l}\text { Research design } \\
\text { (intervention) }\end{array}$} & \multirow{2}{*}{$\begin{array}{l}\text { Sample } \\
\text { N (Age) }\end{array}$} & \multirow{2}{*}{$\begin{array}{l}\text { Data collection } \\
\text { approach }\end{array}$} & \multirow[t]{2}{*}{ Key findings } & \multirow{2}{*}{$\begin{array}{l}\text { Connolly et al. } \\
\text { scale score }\end{array}$} \\
\hline & & & & & & \\
\hline $\begin{array}{l}\text { Checa-Romero } \\
\text { and Pascual } \\
\text { Gómez (2018) }\end{array}$ & $\begin{array}{l}\text { Examining } \\
\text { empirical evidence } \\
\text { of creativity } \\
\text { development } \\
\text { using MC in the } \\
\text { classroom }\end{array}$ & $\begin{array}{l}\text { Students were enrolled } \\
\text { in eight-weeks MC } \\
\text { workshop and asked } \\
\text { to build 'the house of } \\
\text { their dreams' }\end{array}$ & $85(11-12)$ & $\begin{array}{l}\text { Pre-test/post-test } \\
\text { through the CREA } \\
\text { Creative Intelligence } \\
\text { Test }\end{array}$ & $\begin{array}{l}\text { - MC and the audio- } \\
\text { visual productions } \\
\text { allowed students to } \\
\text { creatively express their } \\
\text { conceptions of the house } \\
\text { of their dreams. } \\
\text { - Using games in } \\
\text { the classroom is a } \\
\text { challenge for educational } \\
\text { institutions and teachers } \\
\text { and students. } \\
\text { - Results show a } \\
\text { significant increase in } \\
\text { creativity highlighting } \\
\text { the needs to be used in } \\
\text { classrooms to develop } \\
\text { innovative educational } \\
\text { contexts. Using MC, } \\
\text { with its high level } \\
\text { of freedom, in an } \\
\text { educational subject } \\
\text { led to an increase in } \\
\text { students' creativity. }\end{array}$ & 12 \\
\hline $\begin{array}{l}\text { Cipollone et al. } \\
\text { (2014) }\end{array}$ & $\begin{array}{l}\text { Discussing the } \\
\text { use of MC as } \\
\text { an educational } \\
\text { tool in a formal } \\
\text { educational setting } \\
\text { in an English class. }\end{array}$ & $\begin{array}{l}\text { Participants were } \\
\text { divided into } 5 \\
\text { groups. MC and } \\
\text { the assignment's } \\
\text { introduced in two } \\
\text { options - using MC to } \\
\text { create their video or } \\
\text { using a camera to video } \\
\text { their story. }\end{array}$ & $20(13-16)$ & $\begin{array}{l}\text { Researchers } \\
\text { observed the } \\
\text { participants' film } \\
\text { and provided a } \\
\text { shared server. } \\
\text { Teachers were } \\
\text { interviewed during } \\
\text { and after the project. }\end{array}$ & $\begin{array}{l}\text { - Students were able to } \\
\text { create narratives using } \\
\text { MC, developing multiple } \\
\text { personalities with a } \\
\text { range of character traits. } \\
\text { - MC gave students } \\
\text { access to a creative } \\
\text { space with less cost. } \\
\text { - Researchers observed } \\
\text { meaningful, useful } \\
\text { interaction between } \\
\text { students and the content } \\
\text { through MC. } \\
\text { - Limitations of the } \\
\text { study: The teacher } \\
\text { was not a technology } \\
\text { supporter, thought } \\
\text { negatively about the use } \\
\text { of MC; some students } \\
\text { were unsuccessful } \\
\text { in the project due to } \\
\text { unfamiliarity with the } \\
\text { game. }\end{array}$ & 9 \\
\hline $\begin{array}{l}\text { Clemenson, } \\
\text { Henningfield, } \\
\text { and Stark (2019) }\end{array}$ & $\begin{array}{l}\text { To test whether the } \\
\text { spatial exploration } \\
\text { of a virtual video } \\
\text { game environment, } \\
\text { can impact the } \\
\text { hippocampus } \\
\text { and lead to an } \\
\text { improvement in } \\
\text { hippocampal- } \\
\text { dependent memory. }\end{array}$ & $\begin{array}{l}\text { Participants were } \\
\text { divided into four } \\
\text { groups, each playing } \\
\text { on custom servers and } \\
\text { focusing on different } \\
\text { aspects of Minecraft } \\
\text { over the course of } 2 \\
\text { weeks. }\end{array}$ & $\begin{array}{l}82 \text { (Avg. } \\
19.83 \text { ) }\end{array}$ & $\begin{array}{l}\text { Data were } \\
\text { collected through } \\
\text { pre and post-tests } \\
\text { and Principal } \\
\text { Components } \\
\text { Analysis using: } \\
\text { Mnemonic } \\
\text { Similarity Task } \\
\text { (MST) and Roaming } \\
\text { Entropy (RE) } \\
\text { measures. }\end{array}$ & $\begin{array}{l}\text { - Three groups } \\
\text { (Directed Building, Free } \\
\text { Exploration, and Explore } \\
\text { and Build groups) show } \\
\text { reliable changes in } \\
\text { the LDI score, greater } \\
\text { improvements than the } \\
\text { Free Building group; } \\
\text { however, no change } \\
\text { was observed in general } \\
\text { recognition memory } \\
\text { measure in the MST, } \\
\text { indicating a specific } \\
\text { improvement in the } \\
\text { highly hippocampal } \\
\text { dependent lure } \\
\text { discrimination metric. } \\
\text { - Researchers observed } \\
\text { improvements in a } \\
\text { hippocampal-dependent } \\
\text { memory task, indicating } \\
\text { that both the kind of } \\
\text { enrichment activity } \\
\text { and the degree of } \\
\text { engagement in the } \\
\text { activity were correlated } \\
\text { with the amount of } \\
\text { improvement. } \\
\bullet \text { Researchers concluded } \\
\text { that "playing the video } \\
\text { game Minecraft can } \\
\text { positively impact } \\
\text { hippocampal function } \\
\text { in the form of improved } \\
\text { memory performance } \\
\text { on tasks unrelated to } \\
\text { activities in the game } \\
\text { itself" (p.11). }\end{array}$ & 11 \\
\hline
\end{tabular}


International Journal of Game-Based Learning

Volume 11 •Issue 4 • October-December 2021

Table 1. Continued

\begin{tabular}{|c|c|c|c|c|c|c|}
\hline \multirow{2}{*}{$\begin{array}{l}\text { Author/ } \\
\text { citation }\end{array}$} & \multirow[t]{2}{*}{ Study aim } & \multirow[t]{2}{*}{$\begin{array}{l}\text { Research design } \\
\text { (intervention) }\end{array}$} & Sample & \multirow[t]{2}{*}{$\begin{array}{l}\text { Data collection } \\
\text { approach }\end{array}$} & \multirow[t]{2}{*}{ Key findings } & \multirow[t]{2}{*}{$\begin{array}{l}\text { Connolly et al. } \\
\text { scale score }\end{array}$} \\
\hline & & & N (Age) & & & \\
\hline Craft (2016) & $\begin{array}{l}\text { Reporting the } \\
\text { use of MC to } \\
\text { supplement } \\
\text { history and foreign } \\
\text { language classes. }\end{array}$ & $\begin{array}{l}\text { Server with a simple } \\
\text { Roman temple was } \\
\text { created to reproduce } \\
\text { the temple. }\end{array}$ & $49(13-18)$ & $\begin{array}{l}\text { The researcher } \\
\text { observes and check } \\
\text { progress and lending } \\
\text { assistance and } \\
\text { comparing pre- and } \\
\text { post-assessments. }\end{array}$ & $\begin{array}{l}\text { - The project was } \\
\text { overall successful; } \\
\text { some evidence being } \\
\text { in the pre- and a post- } \\
\text { written assessment on } \\
\text { student understanding } \\
\text { of Roman architecture. } \\
\text { Performance increased } \\
\text { from } 13 \% \text { (answers } \\
\text { correct) in the pre-test to } \\
60 \% \text { in the post-test. } \\
\text { - Some students } \\
\text { completed the tasks } \\
\text { before the deadline. } \\
\text { Some reported it was } \\
\text { overwhelming for them } \\
\text { to find information } \\
\text { about their temple or } \\
\text { were distracted, but after } \\
\text { including a step by step } \\
\text { instruction, confidence } \\
\text { in the use of MC } \\
\text { increased. }\end{array}$ & 8 \\
\hline $\begin{array}{l}\text { (Egbert \& } \\
\text { Borysenko, 2019) }\end{array}$ & $\begin{array}{l}\text { To test whether the } \\
\text { use of the TESOL } \\
\text { Technology } \\
\text { Standards (TTS) } \\
\text { and engagement } \\
\text { principles as a } \\
\text { foundation for } \\
\text { language tasks in } \\
\text { Minecraft facilitate } \\
\text { teacher classroom } \\
\text { learning. }\end{array}$ & $\begin{array}{l}\text { Students were placed } \\
\text { in } 12 \text {-weeks of a } \\
\text { course focusing on } \\
\text { an introduction to } \\
\text { computer-assisted } \\
\text { language learning } \\
\text { (CALL) for pre- and } \\
\text { in-service language } \\
\text { teacher education } \\
\text { students using } \\
\text { Minecraft. }\end{array}$ & $15(\leq 19)$ & $\begin{array}{l}\text { Three data sources } \\
\text { were analysed: } \\
\text { students' tasks } \\
\text { documents (they } \\
\text { participated in } \\
\text { presentations, } \\
\text { discussions, and } \\
\text { completed reflection } \\
\text { about the task as } \\
\text { well as completing } \\
\text { a speaking and } \\
\text { listening task for the } \\
\text { topic of knowledge/ } \\
\text { skills acquisition), } \\
\text { Minecraft tasks } \\
\text { (weekly } 90 \text { min. } \\
\text { task), and students } \\
\text { end course } \\
\text { evaluations. }\end{array}$ & $\begin{array}{l}\text { - Students reported that } \\
\text { they had learned the } \\
\text { basics of technology } \\
\text { knowledge and skills } \\
\text { and are able to teach } \\
\text { some of these basics } \\
\text { to others. They made } \\
\text { positive comments } \\
\text { about their experiences } \\
\text { with Minecraft and that } \\
\text { it is developed their } \\
\text { communicative skills } \\
\text { and facilitate group } \\
\text { collaboration. } \\
\text { - The course helped } \\
\text { students to engage with } \\
\text { each other (Minecraft } \\
\text { prompted discussion } \\
\text { because it was used } \\
\text { with language learners, } \\
\text { which were planned to } \\
\text { help students to learn } \\
\text { about the effectiveness } \\
\text { of CALL based on } \\
\text { learning principles) and } \\
\text { allow them to focus on } \\
\text { the knowledge they most } \\
\text { wanted/needed to gain. } \\
\text { - Students were } \\
\text { observed exhibiting } \\
\text { and perceiving constant } \\
\text { involvement in working } \\
\text { on their Minecraft task } \\
\text { or on their houses/stores } \\
\text { after class and/or before } \\
\text { the next class session. } \\
\text { About } 73 \% \text { of the } \\
\text { students said that they } \\
\text { would definitely use } \\
\text { Minecraft in their future } \\
\text { teaching. }\end{array}$ & 10 \\
\hline
\end{tabular}


International Journal of Game-Based Learning

Volume 11 •Issue 4 • October-December 2021

Table 1. Continued

\begin{tabular}{|c|c|c|c|c|c|c|}
\hline \multirow{2}{*}{$\begin{array}{l}\text { Author/ } \\
\text { citation }\end{array}$} & \multirow[t]{2}{*}{ Study aim } & \multirow{2}{*}{$\begin{array}{l}\text { Research design } \\
\text { (intervention) }\end{array}$} & \multirow{2}{*}{$\begin{array}{l}\text { Sample } \\
\text { N (Age) }\end{array}$} & \multirow{2}{*}{$\begin{array}{l}\text { Data collection } \\
\text { approach }\end{array}$} & \multirow[t]{2}{*}{ Key findings } & \multirow{2}{*}{$\begin{array}{l}\text { Connolly et al. } \\
\text { scale score }\end{array}$} \\
\hline & & & & & & \\
\hline Elliott (2014)* & $\begin{array}{l}\text { Finding ways to } \\
\text { develop curriculum } \\
\text { in English and } \\
\text { Humanities class } \\
\text { using "non-linear } \\
\text { new media text". }\end{array}$ & $\begin{array}{l}\text { Purpose of using MC } \\
\text { was to explore ways to } \\
\text { develop curriculum and } \\
\text { engage students who } \\
\text { have major reading, } \\
\text { writing and behavioural } \\
\text { issues. }\end{array}$ & $\begin{array}{l}\text { N/D (Avg. } \\
14)\end{array}$ & $\begin{array}{l}\text { The researcher } \\
\text { interviewed } \\
\text { students, teachers; } \\
\text { used formative } \\
\text { surveys; collected } \\
\text { Snapshots, text } \\
\text { record, video game } \\
\text { levels, pictures and } \\
\text { classroom audio. }\end{array}$ & $\begin{array}{l}\text { - Some students } \\
\text { engaged deeply with } \\
\text { the games and reported } \\
\text { highly desirable } \\
\text { schoolwork. } \\
\text { - The study focused } \\
\text { on a case study of a } \\
\text { teenager who had poor } \\
\text { school attendance and } \\
\text { difficulties with learning } \\
\text { space. After introducing } \\
\text { MC, the student became } \\
\text { more confident to share } \\
\text { his expertise of MC; } \\
\text { his social interaction } \\
\text { increased; His attitude } \\
\text { toward school become } \\
\text { more positive; he began } \\
\text { to engage in traditional } \\
\text { activities and more } \\
\text { interested talking to } \\
\text { teachers. } \\
\text { - Limitations of the } \\
\text { study: limited to one } \\
\text { case study, and the } \\
\text { number, age, and } \\
\text { gender of students were } \\
\text { missing. }\end{array}$ & 9 \\
\hline Hill (2015)* & $\begin{array}{l}\text { Describing a } \\
\text { library project } \\
\text { exploring } \\
\text { innovative options } \\
\text { for embedding } \\
\text { information } \\
\text { literacy skills by } \\
\text { utilizing MC. }\end{array}$ & $\begin{array}{l}\text { The MC club met in the } \\
\text { school library. Students } \\
\text { choose to lead a role } \\
\text { in building a virtual } \\
\text { world library, with all } \\
\text { its facilities with digital } \\
\text { citizenship. }\end{array}$ & $8(10-11)$ & $\begin{array}{l}\text { Observations for } \\
\text { children's activity } \\
\text { in the virtual library } \\
\text { from October } 2013 \\
\text { through April } 2014 \text {; } \\
\text { interviews about } \\
\text { their experience } \\
\text { during the last } \\
\text { month of the } \\
\text { project; and mixed } \\
\text { reality videos, both } \\
\text { in the physical } \\
\text { school library and in } \\
\text { the virtual world. }\end{array}$ & $\begin{array}{l}\text { - Students allowed } \\
\text { adapting their own } \\
\text { expertise skills, e.g., } \\
\text { one student showing } \\
\text { strong leading skills } \\
\text { took the role of the } \\
\text { game designer; another } \\
\text { became computer } \\
\text { technician ...etc. } \\
\text { - The researcher } \\
\text { reported a strong } \\
\text { observation of } \\
\text { engagement in } \\
\text { programming and } \\
\text { developing MC. } \\
\text { Collaboration, } \\
\text { critical thinking and } \\
\text { constructing the virtual } \\
\text { works were observed, } \\
\text { embedded in digital } \\
\text { citizenship. Students } \\
\text { reported positive } \\
\text { learning. } \\
\text { - Limitations: after a } \\
\text { month the librarian's } \\
\text { laptop crashed, and the } \\
\text { whole project was lost. }\end{array}$ & 8 \\
\hline $\begin{array}{l}\text { Marcon and } \\
\text { Faulkner (2016) }\end{array}$ & $\begin{array}{l}\text { Examining the } \\
\text { use of MC as an } \\
\text { academic tool to } \\
\text { motivate girls' } \\
\text { literacy practices } \\
\text { in the English } \\
\text { classroom. }\end{array}$ & $\begin{array}{l}\text { The study lasted two } \\
\text { weeks of } 9 \text { meetings. } \\
\text { The unit of MC was } \\
\text { added to bridge the gap } \\
\text { between formal and } \\
\text { informal learning. }\end{array}$ & $14(12-13)$ & $\begin{array}{l}\text { Data collected } \\
\text { through } \\
\text { observations, } \\
\text { interviewing two } \\
\text { girls, a survey } \\
\text { and screenshots; } \\
\text { and students' MC } \\
\text { posts/comments } \\
\text { on Instagram and } \\
\text { Facebooks. }\end{array}$ & $\begin{array}{l}\text { - Girls reported that } \\
\text { MC was an attractive } \\
\text { text for literacy learning } \\
\text { and helped them } \\
\text { collaboratively and } \\
\text { strategically in designing } \\
\text { and immersing } \\
\text { themselves in the game } \\
\text { world purposefully as } \\
\text { well as allowing them } \\
\text { to use problem-solving } \\
\text { skills and negotiations } \\
\text { for distributed learning } \\
\text { initiatives. } \\
\text { - Girls used expressive } \\
\text { language to pursue } \\
\text { assistance from other } \\
\text { players and provide } \\
\text { the meaning of their } \\
\text { actions and expressed } \\
\text { their interest and gaming } \\
\text { activities within their } \\
\text { online social tools, } \\
\text { indicate more engaging } \\
\text { learning beyond the } \\
\text { classroom. }\end{array}$ & 9 \\
\hline
\end{tabular}


International Journal of Game-Based Learning

Volume 11 • Issue 4 • October-December 2021

Table 1. Continued

\begin{tabular}{|c|c|c|c|c|c|c|}
\hline \multirow{2}{*}{$\begin{array}{l}\text { Author/ } \\
\text { citation }\end{array}$} & \multirow[t]{2}{*}{ Study aim } & \multirow{2}{*}{$\begin{array}{l}\text { Research design } \\
\text { (intervention) }\end{array}$} & Sample & \multirow{2}{*}{$\begin{array}{l}\text { Data collection } \\
\text { approach }\end{array}$} & \multirow[t]{2}{*}{ Key findings } & \multirow{2}{*}{$\begin{array}{l}\text { Connolly et al. } \\
\text { scale score }\end{array}$} \\
\hline & & & N (Age) & & & \\
\hline Marlatt (2018a) & $\begin{array}{l}\text { Exploring the use } \\
\text { of digital literacies } \\
\text { to support student- } \\
\text { centred literary } \\
\text { analysis }\end{array}$ & $\begin{array}{l}\text { Students read a novel } \\
\text { together, then conduct } \\
\text { a literary analysis with } \\
\text { MC in three } 90 \text {-minute } \\
\text { gaming sessions. }\end{array}$ & $1(18)$ & $\begin{array}{l}\text { Observation } \\
\text { how one student, } \\
\text { Stella, engaged } \\
\text { with the novel } \\
\text { and the literary } \\
\text { analysis in MC; and } \\
\text { interviewed her for } 3 \\
\text { times to understand } \\
\text { concepts behind } \\
\text { what she produced } \\
\text { via MC and how } \\
\text { those activities are } \\
\text { related to the text. }\end{array}$ & $\begin{array}{l}\text { - Stella's crafted well } \\
\text { scenes that linked to } \\
\text { the reading of the text, } \\
\text { showing detailed and } \\
\text { sustained engagement } \\
\text { well with literature. } \\
\text { - She demonstrated } \\
\text { an understanding of } \\
\text { literacy potential for } \\
\text { impacting families and } \\
\text { society, showing critical } \\
\text { awareness of social } \\
\text { inequality and prejudice } \\
\text { in sociocultural } \\
\text { interaction. } \\
\text { - Players showed } \\
\text { strategy and problem } \\
\text { solving, and her analysis } \\
\text { offers her new lenses to } \\
\text { examine her identity. }\end{array}$ & 6 \\
\hline Marlatt (2018b) & $\begin{array}{l}\text { To describes } \\
\text { students' } \\
\text { engagement in the } \\
\text { literary analysis of } \\
\text { a novel using MC. }\end{array}$ & $\begin{array}{l}\text { The novel was read } \\
\text { with the students, } \\
\text { and they asked to } \\
\text { re-create two scenes } \\
\text { of their choice from } \\
\text { each chapter using } \\
\text { MC instead of daily } \\
\text { comprehension } \\
\text { quizzes or vocabulary } \\
\text { worksheets. }\end{array}$ & $1(20)$ & $\begin{array}{l}\text { Data collected } \\
\text { through observations } \\
\text { of player' moves } \\
\text { on the screens and } \\
\text { observing their } \\
\text { social and textual } \\
\text { interaction. The } \\
\text { observed player is } \\
\text { from a minority and } \\
\text { had experienced } \\
\text { failure in literacy. }\end{array}$ & $\begin{array}{l}\text { - Through MC players } \\
\text { were excited about } \\
\text { literature. } \\
\text { • Yem (the observed } \\
\text { player) was creative } \\
\text { and enjoyed gaming } \\
\text { and reported that it is } \\
\text { the first time he was } \\
\text { given a choice on what } \\
\text { and how to read in high } \\
\text { school. MC motivated } \\
\text { him to engage with the } \\
\text { text and was a vehicle } \\
\text { for his during-reading } \\
\text { visualization. } \\
\text { - MC offered the } \\
\text { students with the } \\
\text { opportunities to } \\
\text { cultivate multicultural } \\
\text { perspectives. } \\
\text { - Offering interesting } \\
\text { readings and numerous } \\
\text { entry points into those } \\
\text { readings for students } \\
\text { is important for social } \\
\text { justice which highlighted } \\
\text { students' diverse literacy } \\
\text { practices }\end{array}$ & 6 \\
\hline
\end{tabular}

continued on following page 
International Journal of Game-Based Learning

Volume 11 •Issue 4 • October-December 2021

Table 1. Continued

\begin{tabular}{|c|c|c|c|c|c|c|}
\hline \multirow{2}{*}{$\begin{array}{l}\text { Author/ } \\
\text { citation }\end{array}$} & \multirow[t]{2}{*}{ Study aim } & \multirow{2}{*}{$\begin{array}{c}\text { Research design } \\
\text { (intervention) }\end{array}$} & \multirow{2}{*}{$\frac{\text { Sample }}{\text { N (Age) }}$} & \multirow{2}{*}{$\begin{array}{l}\text { Data collection } \\
\text { approach }\end{array}$} & \multirow[t]{2}{*}{ Key findings } & \multirow{2}{*}{$\begin{array}{l}\text { Connolly et al. } \\
\text { scale score }\end{array}$} \\
\hline & & & & & & \\
\hline $\begin{array}{l}\text { McColgan, } \\
\text { Colesante, and } \\
\text { Andrade (2018) }\end{array}$ & $\begin{array}{l}\text { To find if a game- } \\
\text { based experience } \\
\text { had an impact } \\
\text { on pre-service } \\
\text { teachers' skills, } \\
\text { beliefs, and } \\
\text { confidence using } \\
\text { games for teaching. }\end{array}$ & $\begin{array}{l}\text { Students were } \\
\text { enrolled in issues } \\
\text { in Contemporary } \\
\text { Education class that } \\
\text { includes using MC } \\
\text { to create lessons for } \\
\text { middle and high school } \\
\text { students. }\end{array}$ & $55(18-23)$ & $\begin{array}{l}\text { Pre-posttest } \\
\text { Likert-scale survey } \\
\text { designed by the } \\
\text { instructor and } \\
\text { align with the } \\
\text { objectives of the } \\
\text { course to evaluate } \\
\text { the effectiveness } \\
\text { of the project, and } \\
\text { "included questions } \\
\text { about students' } \\
\text { attitudes, time using } \\
\text { social media, time } \\
\text { spent on games } \\
\text { and gaming with } \\
\text { technology, and skill } \\
\text { with technology."; } \\
\text { and reflection } \\
\text { essays. }\end{array}$ & $\begin{array}{l}\text { - Most groups decided } \\
\text { to create lessons in } \\
\text { STEM topics regardless } \\
\text { of their own major. } \\
\text { Mean scores were higher } \\
\text { at the post-test than the } \\
\text { pre-test for perceptions } \\
\text { of skill using technology } \\
\text { and confidence with new } \\
\text { technologies, with no } \\
\text { gender differences. } \\
\text { - Three themes of } \\
\text { positive changes in } \\
\text { the classroom and } \\
\text { their beliefs of using } \\
\text { MC emerged, which } \\
\text { are the acquisition } \\
\text { of knowledge/ skills; } \\
\text { engagement; and } \\
\text { collaborative interaction. } \\
\text { - They mentioned five } \\
\text { barriers, including the } \\
\text { steep learning curve, } \\
\text { time, and complexity } \\
\text { for teachers, student } \\
\text { distractibility, and } \\
\text { complexity for students } \\
\text { to learn the game. } \\
\text { Pre-service teachers } \\
\text { were sceptical of using } \\
\text { games for teaching in the } \\
\text { classroom. }\end{array}$ & 11 \\
\hline $\begin{array}{l}\text { Moffat et al. } \\
(2017)\end{array}$ & $\begin{array}{l}\text { Testing three } \\
\text { games' impact on } \\
\text { creativity. }\end{array}$ & $\begin{array}{l}\text { Participants asked to } \\
\text { play one of three games } \\
\text { for } 30 \text { minutes: puzzle, } \\
\text { sandbox, or a first- } \\
\text { person shooter. }\end{array}$ & $21(18-30)$ & $\begin{array}{l}\text { Participants } \\
\text { completed a } \\
\text { survey afterwards. } \\
\text { Creativity was } \\
\text { measured by the } \\
\text { Torrance Tests of } \\
\text { Creative Thinking } \\
\text { (TTCT). }\end{array}$ & $\begin{array}{l}\text { - Sandbox game affected } \\
\text { creativity the least of the } \\
\text { three types of games. } \\
\text { Flexibility, as a form of } \\
\text { creativity, was affected } \\
\text { much more than fluency } \\
\text { and originality, which } \\
\text { had not been impacted } \\
\text { much in this experiment } \\
\text { - players had little or } \\
\text { unobservable change in } \\
\text { the fluency or originality } \\
\text { in their ideas. } \\
\text { - Video games engage } \\
\text { students creatively; this } \\
\text { temporary effect on } \\
\text { creativity was differs } \\
\text { based on the game type. }\end{array}$ & 10 \\
\hline $\begin{array}{l}\text { Nebel, Schneider, } \\
\text { Schledjewsk, et } \\
\text { al. (2017) }\end{array}$ & $\begin{array}{l}\text { Presenting a } \\
\text { comparison of } \\
\text { different goal } \\
\text { types within an } \\
\text { educational video } \\
\text { game, using MC as } \\
\text { a content creation } \\
\text { tool. }\end{array}$ & $\begin{array}{l}\text { Three groups of } \\
\text { students (specific } \\
\text { performance goal, } \\
\text { specific learning goal, } \\
\text { goal-free condition) did } \\
5 \text { tasks to learn about } \\
\text { the basic elements of } \\
\text { computer science and } \\
\text { electrical engineering. }\end{array}$ & $87(17-31)$ & $\begin{array}{l}\text { Some observations } \\
\text { and surveys were } \\
\text { used to measure } \\
\text { outcomes: The } \\
\text { survey was on } \\
\text { Current Motivation; } \\
\text { Cognitive Load } \\
\text { Measurement; } \\
\text { Survey for retention, } \\
\text { transfer and far } \\
\text { transfer; and } \\
\text { participants rated } \\
\text { the fun they had. }\end{array}$ & $\begin{array}{l}\text { - Having specific } \\
\text { learning goals lowered } \\
\text { extraneous and intrinsic } \\
\text { cognitive load; players } \\
\text { reported more fun and } \\
\text { effective impacts of } \\
\text { goal-setting and deeper } \\
\text { motivational processes. } \\
\text { - In the goal groups, } \\
\text { participants showed } \\
\text { anger, impatience or } \\
\text { confusion after not } \\
\text { being able to reach their } \\
\text { goal. Participants in } \\
\text { the goal-free condition } \\
\text { started by reading the } \\
\text { task information and } \\
\text { then tried to solve the } \\
\text { tasks, whereas the } \\
\text { specific performance } \\
\text { group read a minimum } \\
\text { of texts to understand } \\
\text { the requirements to solve } \\
\text { the tasks. However, no } \\
\text { significant change in } \\
\text { learning performance } \\
\text { was found. }\end{array}$ & 13 \\
\hline
\end{tabular}


International Journal of Game-Based Learning

Volume 11 •Issue 4 • October-December 2021

Table 1. Continued

\begin{tabular}{|c|c|c|c|c|c|c|}
\hline \multirow{2}{*}{$\begin{array}{l}\text { Author/ } \\
\text { citation }\end{array}$} & \multirow[t]{2}{*}{ Study aim } & \multirow{2}{*}{$\begin{array}{l}\text { Research design } \\
\text { (intervention) }\end{array}$} & \multirow{2}{*}{$\frac{\text { Sample }}{\text { N (Age) }}$} & \multirow{2}{*}{$\begin{array}{l}\text { Data collection } \\
\text { approach }\end{array}$} & \multirow[t]{2}{*}{ Key findings } & \multirow{2}{*}{$\begin{array}{c}\text { Connolly et al. } \\
\text { scale score }\end{array}$} \\
\hline & & & & & & \\
\hline Petry $(2018)^{*}$ & $\begin{array}{l}\text { Examining } \\
\text { children's } \\
\text { conception of } \\
\text { the relationship } \\
\text { between work/ } \\
\text { labour and leisure } \\
\text { in game playing. }\end{array}$ & $\begin{array}{l}\text { No intervention } \\
\text { reported. The } \\
\text { researcher observed } \\
\text { some playing sessions. }\end{array}$ & $5(6-12)$ & $\begin{array}{l}\text { Semi-structured } \\
\text { interviews and } \\
5 \text { play sessions } \\
\text { recorded of children } \\
\text { who identified } \\
\text { themselves to be } \\
\text { MC fans. }\end{array}$ & $\begin{array}{l}\text { - YouTube and books } \\
\text { stated as the main } \\
\text { resources for learning } \\
\text { about how to play and } \\
\text { be creative. Children } \\
\text { indicated some aspect of } \\
\text { learning from the game. } \\
\text { MC helped them to } \\
\text { collaborate with others, } \\
\text { engage, discuss, and } \\
\text { share knowledge. } \\
\text { - However, most } \\
\text { children had never heard } \\
\text { the word 'labour' in } \\
\text { playing; instead, they } \\
\text { use 'work'. } \\
\text { - The play involved } \\
\text { much work, requiring a } \\
\text { state of mind and fun; } \\
\text { when players lose the } \\
\text { fun, they lose the game. }\end{array}$ & 7 \\
\hline Quiring (2015) & $\begin{array}{l}\text { Bridging gaps } \\
\text { between the } \\
\text { literature and } \\
\text { research on virtual } \\
\text { worlds. }\end{array}$ & $\begin{array}{l}\text { No intervention was } \\
\text { reported. }\end{array}$ & 1 (N/D) & $\begin{array}{l}\text { MC analysed } \\
\text { through the } \\
\text { researcher's own } \\
\text { experience and } \\
\text { analysis of gameplay } \\
\text { videos uploaded to } \\
\text { YouTube. }\end{array}$ & $\begin{array}{l}\text { - MC discussion } \\
\text { was based on the } \\
\text { themes of Alteration/ } \\
\text { Change - players' } \\
\text { ability to alter their } \\
\text { virtual environment; } \\
\text { Proximity - MC space } \\
\text { to participate in shared } \\
\text { projects and events; } \\
\text { Conflict/Cooperation } \\
\text {-the multiplayer servers } \\
\text { where players centre } \\
\text { on specific projects } \\
\text { and negotiate conflicts. } \\
\text { MC is no less real or } \\
\text { meaningful than human } \\
\text { interaction outside the } \\
\text { game. }\end{array}$ & 5 \\
\hline $\begin{array}{l}\text { Sáez-López et al. } \\
\text { (2015) }\end{array}$ & $\begin{array}{l}\text { Evaluating the } \\
\text { use and outcomes } \\
\text { of MCEdu and } \\
\text { discussing attitudes } \\
\text { of the educational } \\
\text { community. }\end{array}$ & $\begin{array}{l}\text { MCEdu was used, } \\
\text { where teachers } \\
\text { developed a unit to } \\
\text { evaluate the outcome of } \\
\text { using this game for the } \\
\text { experimental group. }\end{array}$ & $\begin{array}{l}\text { Stage A) } \\
181 \\
(11-14) \\
\text { Stage B) } \\
205 \\
\text { (N/D) } \\
\text { Stage C) } \\
131 \text { (11- } \\
14)\end{array}$ & $\begin{array}{l}\text { A) Learning, of } \\
131 \text { students in the } \\
\text { experimental group } \\
\text { (MC group), and } 50 \\
\text { in the control group } \\
\text { assessed through } \\
\text { formal tests. } \\
\text { B) Surveys to } \\
\text { analysis the attitude } \\
\text { of parents, teachers } \\
\text { and students } \\
\text { regarding the use of } \\
\text { MCEdu. } \\
\text { C) Qualitative } \\
\text { analysis of an online } \\
\text { discussion platform. }\end{array}$ & $\begin{array}{l}\text { - Test results of the } \\
\text { academic unit did not } \\
\text { show a significant } \\
\text { difference between the } \\
\text { experimental and the } \\
\text { control groups. } \\
\text { - } 98.5 \% \text { of participants } \\
\text { thought MCEdu was } \\
\text { fun; enables discovery } \\
\text { (96.6\%), encourages } \\
\text { learning ( } 97.1 \%) \text {, } \\
\text { enables rich interactions } \\
\text { (96.6\%), and enhances } \\
\text { creativity ( } 96.1 \%) \text { and } \\
\text { learning ( } 83.4 \%) \text {. } \\
\text { - Students interacted } \\
\text { with each other in } \\
\text { English although there } \\
\text { were some from Spain } \\
\text { and the USA. } \\
\text { - Limitations of the } \\
\text { game: } 24 \text { people } \\
\text { thought the school lost } \\
\text { time applying it and } \\
36 \text { people thought it } \\
\text { should be used outside } \\
\text { the classroom. Parents } \\
\text { were the most negative } \\
\text { regarding these two } \\
\text { points, with } 79.1 \% \text { and } \\
75 \% \text { of the frequencies, } \\
\text { respectively. }\end{array}$ & 13 \\
\hline
\end{tabular}


International Journal of Game-Based Learning

Volume 11 •Issue 4 • October-December 2021

Table 1. Continued

\begin{tabular}{|c|c|c|c|c|c|c|}
\hline \multirow{2}{*}{$\begin{array}{l}\text { Author/ } \\
\text { citation }\end{array}$} & \multirow[t]{2}{*}{ Study aim } & \multirow{2}{*}{$\begin{array}{l}\text { Research design } \\
\text { (intervention) }\end{array}$} & Sample & \multirow{2}{*}{$\begin{array}{l}\text { Data collection } \\
\text { approach }\end{array}$} & \multirow[t]{2}{*}{ Key findings } & \multirow{2}{*}{$\begin{array}{l}\text { Connolly et al. } \\
\text { scale score }\end{array}$} \\
\hline & & & N (Age) & & & \\
\hline Saito et al. (2017) & $\begin{array}{l}\text { Examining whether } \\
\text { a visual-based } \\
\text { input method } \\
\text { induces a } \\
\text { different attitude } \\
\text { or outcomes of } \\
\text { programming. }\end{array}$ & $\begin{array}{l}\text { Participants attended a } \\
\text { lecture, which taught } \\
\text { the basic concepts } \\
\text { of programming } \\
\text { environments. }\end{array}$ & $72(6-15)$ & $\begin{array}{l}\text { Pre- and post- } \\
\text { questionnaires } \\
\text { given to participants } \\
\text { before and after the } \\
\text { lecture, assessing: } \\
\text { Interest, Difficulty, } \\
\text { Usefulness, Fun, and } \\
\text { Willingness with } \\
\text { five Likert scales. }\end{array}$ & $\begin{array}{l}\text { - Participants' attitudes } \\
\text { for interest, difficulty, } \\
\text { and fun towards } \\
\text { programming improved } \\
\text { and became positive. } \\
\text { The results included that } \\
\text { the Visual Group had a } \\
\text { larger positive change } \\
\text { in the attitude toward } \\
\text { programming than the } \\
\text { Text Group. } \\
\text { - The visual input } \\
\text { increases positive } \\
\text { attitudes towards } \\
\text { programming more than } \\
\text { the text input method } \\
\text { and seems to be great } \\
\text { for an introduction } \\
\text { to programming and } \\
\text { in a programming } \\
\text { implementation } \\
\text { environment for first } \\
\text { learners. } \\
\text { - Limitations of the } \\
\text { study: groups were } \\
\text { unbalanced. }\end{array}$ & 10 \\
\hline $\begin{array}{l}\text { Smolčec and } \\
\text { Smolčec (2014) }\end{array}$ & $\begin{array}{l}\text { Reporting on } \\
\text { how MC has } \\
\text { helped their son } \\
\text { with developing } \\
\text { language skills. }\end{array}$ & $\begin{array}{l}\text { No intervention was } \\
\text { reported. }\end{array}$ & $1(10)$ & $\begin{array}{l}\text { Observation for their } \\
\text { son's monitoring } \\
\text { their work online } \\
\text { playing MC and } \\
\text { the impact on his } \\
\text { linguistics skills of } \\
\text { listening, speaking } \\
\text { and writing. }\end{array}$ & $\begin{array}{l}\text { - MC helped the child to } \\
\text { learn collaboration and } \\
\text { build friendships. They } \\
\text { learned vocabulary, } \\
\text { which helped them to } \\
\text { be more confident as a } \\
\text { speaker and as a writer. } \\
\text { Different English skills } \\
\text { were learnt by watching } \\
\text { YouTube videos. } \\
\text { - Limitations of the } \\
\text { game/study: the child } \\
\text { learnt inappropriate } \\
\text { language through } \\
\text { interacting with others, } \\
\text { such as swearing, and } \\
\text { developed an addiction, } \\
\text { some spent too much } \\
\text { time playing rather than } \\
\text { doing other activities. }\end{array}$ & 7 \\
\hline Swier (2014) & $\begin{array}{l}\text { Considering } \\
\text { goal-orientated } \\
\text { communicative } \\
\text { tasks for virtual } \\
\text { worlds, adopting } \\
\text { MC as a platform } \\
\text { of choice. }\end{array}$ & $\begin{array}{l}\text { Three goal-orientated } \\
\text { tasks that involve } \\
\text { some exploration } \\
\text { and modification } \\
\text { of the environment } \\
\text { were designed by the } \\
\text { participants. }\end{array}$ & $6(19-29)$ & $\begin{array}{l}\text { Pre- and post- Likert } \\
\text { questionnaires using } \\
\text { a five-point scale to } \\
\text { explore the attitudes } \\
\text { of the participants } \\
\text { towards completing } \\
\text { goal-orientated } \\
\text { tasks in MC; and } \\
\text { a semi-interview } \\
\text { about completing } \\
\text { the task. }\end{array}$ & $\begin{array}{l}\text { - MC is a useful } \\
\text { platform for developing } \\
\text { communication skills } \\
\text { for language learners; } \\
\text { negotiation was clearly } \\
\text { observable; linguistic } \\
\text { interaction between } \\
\text { players decreased during } \\
\text { periods where players } \\
\text { were not faced with an } \\
\text { immediate goal, such } \\
\text { as solving a problem } \\
\text { or making a decision. } \\
\text { Participants completed } \\
\text { the tasks in the same } \\
\text { amount of time; stating } \\
\text { that their communicative } \\
\text { interaction improved } \\
\text { their English. } \\
\text { - Limitations of the } \\
\text { study: the sample is } \\
\text { small. }\end{array}$ & 9 \\
\hline
\end{tabular}




\begin{tabular}{|c|c|c|c|c|c|c|}
\hline \multirow{2}{*}{$\begin{array}{l}\text { Author/ } \\
\text { citation }\end{array}$} & \multirow[t]{2}{*}{ Study aim } & \multirow{2}{*}{$\begin{array}{l}\text { Research design } \\
\text { (intervention) }\end{array}$} & Sample & \multirow{2}{*}{$\begin{array}{l}\text { Data collection } \\
\text { approach }\end{array}$} & \multirow[t]{2}{*}{ Key findings } & \multirow{2}{*}{$\begin{array}{l}\text { Connolly et al. } \\
\text { scale score }\end{array}$} \\
\hline & & & N (Age) & & & \\
\hline $\begin{array}{l}\text { Wernholm and } \\
\text { Vigmo }(2015)^{*}\end{array}$ & $\begin{array}{l}\text { Attempt to find } \\
\text { how online } \\
\text { technologies could } \\
\text { influence data } \\
\text { collection chances } \\
\text { and process. }\end{array}$ & $\begin{array}{l}\text { Children played as one } \\
\text { community on the same } \\
\text { server. Their playing } \\
\text { was recorded using } \\
\text { FRAPS software. }\end{array}$ & $3(>15)$ & $\begin{array}{l}\text { FRAPS - an online } \\
\text { tool, allowing } \\
\text { players to video } \\
\text { record their play } \\
\text { was used and then } \\
\text { the dialogues } \\
\text { were transcribed } \\
\text { and analysed in } \\
\text { regarding: Which of } \\
\text { all these dialogues } \\
\text { can be characterized } \\
\text { as knowledge- } \\
\text { making dialogues. }\end{array}$ & $\begin{array}{l}\text { - FRAPS helps } \\
\text { researchers get closer } \\
\text { to children, and not } \\
\text { distribute children's } \\
\text { participation. } \\
\text { Participants' interactions } \\
\text { were in the Swedish } \\
\text { language and English } \\
\text { concepts. Analysis of the } \\
\text { video recordings showed } \\
\text { players gained and } \\
\text { shared knowledge and } \\
\text { became better through } \\
\text { collaboration with the } \\
\text { language use. } \\
\text { - Limitations of the } \\
\text { study - children, } \\
\text { expressed annoyance } \\
\text { when having technical } \\
\text { problems. }\end{array}$ & 8 \\
\hline
\end{tabular}

* Social and communication learning is a secondary outcome for these studies.

2018). Sanz-Martos, Martínez-Martínez, and Creus (2018) studies the sense of online community and behaviour in online discussion platform. They reported that different behaviour depending on the communication space, but Minecraft community recognise each other and even inform others if one planned to be absent for a while, conversely to YouTube where participation follow any user, and it is not necessary to be subscribed to the channel. The study also found that members of the community tend to be grouped into teams of acquaintances, and they find the game's form is a place for exchanges of messages and information. The researchers (Sanz-Martos et al., 2018) concluded that although the number of viewers and the unorganized arrangement of the comments prevents the establishment of a community, there was enough evidence that users shared and exchanged knowledge, and they undoubtedly learn.

Furthermore, Niemeyer and Gerber (2015) found that sharing videos of play experiences via YouTube provided something to the viewer, such as how to complete a task, how to create a server, or how to build or craft something within the game. Some players expressed their own preference on how to build something, which allowed other players to enhance their gameplay, while others engaged in discussions about tasks, as well as exchanging feedback and ideas, with creators providing informative and entertaining comments (Niemeyer \& Gerber, 2015). Similarly, Bebbington and Vellino (2015) reviewed and analysed online discussion platform and reported that five threads were posted as a request for technical information, twelve threads aimed to express strategic information and three endeavoured to learn about others' opinions. In addition, Hong-An (2016) undertook a similar project analysing twenty-five discussion threads. The researcher indicated that threads gave players opportunities to exchange news and legal and technical changes and to share a narrative, visual opinions, cultural and gaming experiences of Minecraft, and acted as self-directed learning, educational, and motivational support for others (Hong-An, 2016). Furthermore, Davis, Boss, and Meas, (2018) reported that participants' communication and discussion during gameplay showed a number of factors that affecting their ability to achieve joint attention and successful collaboration, such as prior social ties, gaming experience, and responsiveness to other players. These actions of exchanging and sharing knowledge, as well as interaction, could help players expand their problemsolving skills and encourage collaborative group learning.

Fostering and maintaining the sharing feeling and providing opportunities for communication and collaboration with others presented an advantage in using Minecraft in the classroom. For example, according to Hill (2015), all players reported positive learning in the digital citizenship library game. Their feelings ranged from being nervous to excited, showing unique evidence of personal interest. Furthermore, Wernholm and Vigmo (2015) found that children expressed being 
annoyed when experiencing a technological problem, expressing and communicating this to each other during the game as meta-conversations, as the ability to manage feeling with others is a key in relationship skill. Playing Minecraft with others resulted in many forms of social and communication interaction in the class, such as discussing, sharing, arguing, and debating (Dezuanni et al., 2015). Although communication and collaboration with others might not constitute the main reason for playing Minecraft, it can be used to develop players' communication and relationship skills, which are necessary for developing children's life skills. Hill (2015) reported that Minecraft players were able to share and adapt their own skills through healthy team communications, and substantial evidence of engagement and collaboration within the team. Critical thinking in constructing the virtual works was observed from students who successfully embedded digital citizenship into an immersive learning environment (Hill, 2015). When enjoying an educational activity, learners can develop collaboration skills without aiming to do so (Quiring, 2015). Additionally, Smolčec and Smolčec (2014) stated that Minecraft helped participants to build friendship skills and develop team skills, aiding players to improve peer-tutoring techniques. Therefore, it could be considered as being an instrument that brought players together to practice communication and collaboration skills in the pursuit of an activity.

Therefore, collaborative (not competitive) learning using Minecraft in the classroom is a key for a successful education system. The task performance of student groups increased when they were required to collaborate, with individual learning outcomes and interactions increasing, and collaboration was used to enable learning (Nebel et al., 2017a). Asking for collaboration or help was also observable in some Minecraft studies. Dezuanni et al. (2015) found that two of the girls participating in this study were perceived as technical experts and one of them moved around the class many times offering help to others. Asking for help and offering help appeared to be necessary for improving the communicative and collaborative skills taught to students in schools. However, using Minecraft as a tool to maintain learners' collaborative and communicative skills was not enough by itself. Dezuanni et al. (2015) highlighted that, although players started to show progress towards the learning levels, some children veered off-topic. This could count as one of the limitations, as Minecraft may present too many distractions for some players.

Leadership skills are important qualities that students need to develop to enhance their confidence and self-esteem; Minecraft is reported as a useful vehicle to this end. Elliott (2014) found that the participant's enthusiasm for school improved due to being involved with Minecraft, students were now seeking his help for guidance and instruction in the game (Elliott, 2014), where Minecraft changed the student's status among his peers as he became a leader and a significant person in this activity. Hollett and Ehret (2017) also reported that back-and-forth movements between one player and another were positive, where one assists them on their project before leaving them to take on the rest of the project independently. The player considered himself to be a teacher developing an initial pedagogy for newcomers and became self-reliant (Hollett \& Ehret, 2017), where he viewed himself as a potential mentor in Minecraft communities. Indeed, leadership skills might be tested and assessed through Minecraft. Therefore, Minecraft allows researchers to develop students' skills, such as their confidence and self-esteem.

\section{DISCUSSION}

Although this review demonstrates that Minecraft presents many significant educational advantages, a number of concerns has also arisen. McColgan et al. (2018) reported that pre-service mentioned five barriers, including the steep learning curve, time, and complexity for teachers, student distractibility, and complexity for students to learn the game; indeed, pre-service teachers were sceptical of using games for teaching in the classroom. This review summarized some of the limitations reported by previous studies, such as the generalizability of learning lessons to the environment outside the game, internet connectivity and suitability, possible side-effect of using games in schools, Minecraft age appropriateness, and the addiction and health concerns. 
Generalisation of learning is a critical issue in teaching a skill through Minecraft. Some have debated whether students can apply what they learn through computer games to the real world. In fact, the concept of reality is another questionable issue in computer games. Quiring's study (2015) argued that "the video game world of Minecraft features physical and social places that, while digital, are no less real or meaningful than those outside the game" (p.14). This author supports that Minecraft is a depiction of real life with equal value, helping them to apply learned skills in real life (Quiring, 2015). More targeted studies are required to address whether the skills and knowledge learned in Minecraft is generalised, and to what degree.

Logistical issues such as internet connectivity and suitability presented one of the greatest concerns. For example, Cipollone et al. (2014) reported the teacher in his study was not a technology supporter and was concerned about America's formal education perspective, which might not support tools like Minecraft. Furthermore, social familiarity was another issue in multiplayer games as one student reported that she did not enjoy playing Minecraft because there were some people on the server that she didn't know; however, other students in the study showed positive thoughts because of the social interaction, which was safely observed (Dezuanni et al., 2015); thus, although technology makes online social interaction more accessible, contact with unfamiliar people might be an issue. Craft (2016) stated that some students who used Minecraft felt overwhelmed; however, after making some iterations, such as including step-by-step instructions of the task to students, confidence in the use of Minecraft increased. The researcher stated, "I find that the best part of implementations of this sort is that we are educating our students about technology, a medium all too familiar to today's generation", (Craft 2016, p.362). However, because Minecraft is an open world, some players lost attention easily, which may have delayed the task's process (Nebel et al., 2017a). Therefore, making sure that the environment is safe and enjoyable for all students is a requirement in order to make learning more interactive and meaningful.

Digital games such as Minecraft, incorporate many distractions and users need to be aware of how to avoid them. Some players may get distracted by the features of the game and lose focus on what they have been asked to do. One player in Hill's study (2015) was distracted on so many occasions that he was removed from the team for two weeks until he promised to follow the team's desired goals, which he later achieved. Another example is when some of the participants mistakenly moved other people's blocks, which caused anger, but they apologised and worked well to fix the area. Therefore, some of the individual problems that arise in gaming can be easily solved; however, the issue becomes difficult when the problems affect the whole project or the whole class. Hill (2015) reported that after a month of working on a library project, the librarian's laptop crashed and the whole project was lost; the players were disappointed because of the loss of the server, which meant they had to rebuild the virtual library again. After the end of the project, researchers reported that the feedback from all testers was positive. Teachers can help prevent distractions by properly introducing the game and using mods to exclude unrelated features.

Nevertheless, Minecraft might not be a suitable tool for all ages; therefore, researchers need to be aware of age appropriateness before implementing a study. Some research considers the ageappropriateness of Minecraft a limitation because it may display some violence (Mavoa, Carter, $\&$ Gibbs, 2017). The controversy is whether the game is child-friendly or contains violence. What is the definition of violence? Is killing a sheep to consume its meat considered violence? This is a grey area that researchers and parents might interpret differently. The ongoing debate concerning Minecraft and violence seems to be based on unproven cases. It should be noted that Minecraft can be used in a variety of modes, such as choose the creative mode, where the players do not need to eat meat; therefore, there is no need to kill animals. On the other hand, according to Willett (2015), the Entertainment Software Rating Board (ESRB) rates the game as suitable for children aged ten years and above, while the Pan European Game Information (PEGI) system rated Minecraft as appropriate for children aged seven years and older (PEGI, 2016). However, Mavoa et al., (2018) reported that children as young as three years old play Minecraft, but older children are more likely to play Minecraft 
International Journal of Game-Based Learning

Volume 11 • Issue 4 • October-December 2021

Table 2. Summary of all included studies about Minecraft (MC) focuses on social and communication learning outcomes

\begin{tabular}{|c|c|c|c|c|c|c|}
\hline \multirow{2}{*}{$\begin{array}{l}\text { Author/ } \\
\text { citation }\end{array}$} & \multirow[t]{2}{*}{ Study aim } & \multirow{2}{*}{$\begin{array}{l}\text { Research design } \\
\text { (intervention) }\end{array}$} & \multirow{2}{*}{$\begin{array}{l}\text { Sample } \\
\text { N (Age) }\end{array}$} & \multirow{2}{*}{$\begin{array}{l}\text { Data collection } \\
\text { approach }\end{array}$} & \multirow[t]{2}{*}{ Key findings } & \multirow{2}{*}{$\begin{array}{c}\text { Connolly } \\
\text { et al. } \\
\text { scale } \\
\text { score }\end{array}$} \\
\hline & & & & & & \\
\hline $\begin{array}{l}\text { Bebbington and } \\
\text { Vellino (2015) }\end{array}$ & $\begin{array}{l}\text { Defining how } \\
\text { information } \\
\text { literacy is used } \\
\text { through MC } \\
\text { and how these } \\
\text { skills were } \\
\text { demonstrated in } \\
\text { informal online } \\
\text { spaces. }\end{array}$ & $\begin{array}{l}\text { No intervention } \\
\text { - researchers } \\
\text { analysed online } \\
\text { discussion threads, } \\
\text { August } 2011 \text { - June } \\
2013 \text {, located from } \\
\text { MCforum.net, and } \\
\text { interviewed MC } \\
\text { players. }\end{array}$ & $8(15-16)$ & $\begin{array}{l}\text { Stage A) analysed online } \\
\text { interaction of } 20 \text { threads } \\
\text { with } 510 \text { participants } \\
\text { in a public dissection } \\
\text { forum. } \\
\text { Stage B) semi-structured } \\
30 \text {-minute interviews } \\
\text { with eight MC players. }\end{array}$ & $\begin{array}{l}\text { - Stage A - } 5 \text { threads } \\
\text { were requesting for } \\
\text { technical information, } \\
12 \text { were expressing } \\
\text { strategic information, } \\
\text { and } 3 \text { endeavoured to } \\
\text { share opinions. } 98.75 \\
\text { days were the average } \\
\text { duration of threads. } \\
\text { - Stage B - } 5 \text { of } \\
\text { interviewees reported } \\
\text { they get information } \\
\text { from MC -focus } \\
\text { resources, used the } \\
\text { trial and error process } \\
\text { to learn, reporting } \\
\text { a different way of } \\
\text { evaluating information. }\end{array}$ & 8 \\
\hline Callaghan (2016) & $\begin{array}{l}\text { Investigating the } \\
\text { role of MC Edu } \\
\text { in collaborative } \\
\text { educational } \\
\text { learning } \\
\text { environments }\end{array}$ & $\begin{array}{l}\text { Two separate } \\
\text { worlds created } \\
\text { on MCEdu. One } \\
\text { created for learning } \\
\text { for the Technology } \\
\text { Applied Studies } \\
\text { (TAS) class and } \\
\text { the other for } \\
\text { socialization for } \\
\text { an MC club (after } \\
\text { school club). }\end{array}$ & $168(12-16)$ & $\begin{array}{l}\text { Observations using a } \\
\text { framework to record } \\
\text { classroom information } \\
\text { data observed all online } \\
\text { activity in real time and } \\
\text { using video recording } \\
\text { software. } \\
\text { An online questionnaire } \\
\text { was given for students, } \\
\text { with Likert scales and } \\
\text { open-ended questions. }\end{array}$ & $\begin{array}{l}\text { - MCEdu used as part } \\
\text { of the teaching and } \\
\text { learning by } 62 \% \text { of } \\
\text { participants. } 72 \% \text { of } \\
\text { students reported the } \\
\text { educational benefits of } \\
\text { using MCEdu in class. } \\
\text { The more students } \\
\text { vocalized, the more } \\
\text { they became productive } \\
\text { in building structures } \\
\text { collaboratively. } \\
\text { - Teacher and } \\
\text { researcher reported that } \\
\text { players were generous } \\
\text { in sharing expertise, } \\
\text { communicating, } \\
\text { creating objects, } \\
\text { problem-solving, and } \\
\text { working collaboratively. } \\
\text { • All students } \\
\text { demonstrated higher } \\
\text { order skills of "create" } \\
\text { and "evaluate" } \\
\text { (Bloom's Taxonomy). }\end{array}$ & 12 \\
\hline Cilauro (2015)* & $\begin{array}{l}\text { To attract } \\
\text { youth, to have } \\
\text { a role in library } \\
\text { programming, } \\
\text { creating social } \\
\text { interaction } \\
\text { opportunities } \\
\text { within the } \\
\text { community. }\end{array}$ & $\begin{array}{l}\text { Participants } \\
\text { engaged in } \\
\text { planning for the } \\
\text { MC Gaming Day, } \\
\text { and they were } \\
\text { given a chance to } \\
\text { critically review } \\
\text { the library space } \\
\text { and employ their } \\
\text { rules in the virtual } \\
\text { library program. }\end{array}$ & $5(\mathrm{~N} / \mathrm{D})$ & $\begin{array}{l}\text { Staff evaluation of } \\
\text { designed library and } \\
\text { focus groups about } \\
\text { their experience in } \\
\text { participation in the } \\
\text { library gaming program. }\end{array}$ & $\begin{array}{l}\text { - Parents were } \\
\text { involved indirectly and } \\
\text { understood the online } \\
\text { behaviour of their } \\
\text { young people. } \\
\text { - Participants were } \\
\text { able to socially interact } \\
\text { with others from } \\
\text { other ethnicities and } \\
\text { cultures, including } \\
\text { disadvantaged young } \\
\text { people to be socially } \\
\text { included in this online } \\
\text { game. This became a } \\
\text { socially engaged tool in } \\
\text { the library. But, Some } \\
\text { of them could not fully } \\
\text { take part due to lack of } \\
\text { access to MC or being } \\
\text { unable to be part of } \\
\text { the group dialogues, } \\
\text { leading to some } \\
\text { isolation. } \\
\text { - Limitations of } \\
\text { the study: - the age } \\
\text { of participants not } \\
\text { reported. }\end{array}$ & 8 \\
\hline
\end{tabular}


International Journal of Game-Based Learning

Volume 11 • Issue 4 • October-December 2021

Table 2. Continued

\begin{tabular}{|c|c|c|c|c|c|c|}
\hline \multirow{2}{*}{$\begin{array}{l}\text { Author/ } \\
\text { citation }\end{array}$} & \multirow[t]{2}{*}{ Study aim } & \multirow{2}{*}{$\begin{array}{l}\text { Research design } \\
\text { (intervention) }\end{array}$} & \multirow{2}{*}{$\begin{array}{l}\text { Sample } \\
\text { N (Age) }\end{array}$} & \multirow{2}{*}{$\begin{array}{l}\text { Data collection } \\
\text { approach }\end{array}$} & \multirow[t]{2}{*}{ Key findings } & \multirow{2}{*}{$\begin{array}{c}\text { Connolly } \\
\text { et al. } \\
\text { scale } \\
\text { score }\end{array}$} \\
\hline & & & & & & \\
\hline $\begin{array}{l}\text { Davis, Boss, and } \\
\text { Meas (2018) }\end{array}$ & $\begin{array}{l}\text { Exploring } \\
\text { collaboration in } \\
\text { MC and factors } \\
\text { support a high } \\
\text { quality of } \\
\text { collaboration. }\end{array}$ & $\begin{array}{l}\text { Three groups of } \\
2-4 \text { students were } \\
\text { invited to build } \\
\text { a summer camp } \\
\text { together in Mc for } \\
\text { one hour. }\end{array}$ & $10(11-13)$ & $\begin{array}{l}\text { Observation, field } \\
\text { notes, and transcripts of } \\
\text { reordered video of the } \\
\text { playing and participants' } \\
\text { utterances using an in- } \\
\text { depth thematic analysis. }\end{array}$ & $\begin{array}{l}\text { - Most of the players' } \\
\text { discussion with each } \\
\text { other included talking } \\
\text { about gameplay and } \\
\text { asking and answering } \\
\text { questions. } \\
\text { - Participants' } \\
\text { communication and } \\
\text { discussion during } \\
\text { gameplay showed } \\
\text { a number of factors } \\
\text { that affecting their } \\
\text { ability to achieve joint } \\
\text { attention and successful } \\
\text { collaboration, such } \\
\text { as prior social ties, } \\
\text { gaming experience, and } \\
\text { responsiveness to other } \\
\text { players. }\end{array}$ & 9 \\
\hline $\begin{array}{l}\text { Dezuanni et al. } \\
(2015)\end{array}$ & $\begin{array}{l}\text { Exploring how } \\
\text { girls undertake } \\
\text { practices of } \\
\text { curatorship to } \\
\text { display their MC } \\
\text { knowledge. }\end{array}$ & $\begin{array}{l}\text { Year } 3 \text { students } \\
\text { and the teacher } \\
\text { played MCEdu, } \\
\text { in the class, and } \\
\text { explore how girls } \\
\text { manage curatorship } \\
\text { in the playing and } \\
\text { discussion of MC. }\end{array}$ & $16(8-9)$ & $\begin{array}{l}\text { Interviews and focus } \\
\text { groups lasted between } \\
15-30 \text { minutes about } \\
\text { the girls' use of use the } \\
\text { MCEdu version and } \\
\text { their home and school } \\
\text { gameplay. }\end{array}$ & $\begin{array}{l}\text { - Year } 3 \text { students } \\
\text { showed positive } \\
\text { thoughts about the } \\
\text { school MC server } \\
\text { because of the social } \\
\text { interaction, occurred } \\
\text { by seeing each other's } \\
\text { screens and by sharing } \\
\text { ideas or solving } \\
\text { problems. } \\
\text { - Playing the game } \\
\text { showed many forms } \\
\text { of social interaction } \\
\text { in the class, such as } \\
\text { discussing, sharing, } \\
\text { arguing, ignoring and } \\
\text { debating. One student, } \\
\text { she did not enjoy the } \\
\text { game socially due to not } \\
\text { knowing some people } \\
\text { on the server. }\end{array}$ & 8 \\
\hline Ellison $(2017)^{*}$ & $\begin{array}{l}\text { Examining how } \\
\text { the participant } \\
\text { (Zack) chose a } \\
\text { topic and created } \\
\text { a digital story; } \\
\text { and the influence } \\
\text { of his racial } \\
\text { identities. }\end{array}$ & $\begin{array}{l}\text { Digital storytelling } \\
\text { workshop held after } \\
\text { school, one hour } \\
\text { a week for seven } \\
\text { weeks as part of a } \\
\text { PTA enrichment } \\
\text { club program for } \\
\text { students at Zack's } \\
\text { school. }\end{array}$ & $1(13)$ & $\begin{array}{l}\text { The researcher observed } \\
\text { Zack seven times, } \\
\text { for one hour each } \\
\text { week, creating audio- } \\
\text { recorded transcripts } \\
\text { from three } 30 \text {-minute } \\
\text { semi-structured and } \\
\text { unstructured interviews. }\end{array}$ & $\begin{array}{l}\text { - The child chose to } \\
\text { create his digital story } \\
\text { using MC, being a sign } \\
\text { of how MC is essential } \\
\text { to him; was able to } \\
\text { plan and map the story } \\
\text { from the beginning } \\
\text { to end creatively and } \\
\text { independently, feeling } \\
\text { comfortable operating } \\
\text { in MC space. He } \\
\text { reported being afforded } \\
\text { opportunities make } \\
\text { decisions, problem } \\
\text { solve and be a critical } \\
\text { thinker within MC } \\
\text { worlds. } \\
\text { - The study helped } \\
\text { researchers understand } \\
\text { how race is an } \\
\text { important part of the } \\
\text { participant, as evidently } \\
\text { presented in his digital } \\
\text { story, allowing him to } \\
\text { build on his literacies, } \\
\text { agency, funds of } \\
\text { knowledge and identity. }\end{array}$ & 7 \\
\hline
\end{tabular}


International Journal of Game-Based Learning

Volume 11 • Issue 4 • October-December 2021

Table 2. Continued

\begin{tabular}{|c|c|c|c|c|c|c|}
\hline \multirow{2}{*}{$\begin{array}{l}\text { Author/ } \\
\text { citation }\end{array}$} & \multirow[t]{2}{*}{ Study aim } & \multirow{2}{*}{$\begin{array}{l}\text { Research design } \\
\text { (intervention) }\end{array}$} & \multirow{2}{*}{$\begin{array}{l}\text { Sample } \\
\mathrm{N} \text { (Age) }\end{array}$} & \multirow{2}{*}{$\begin{array}{l}\text { Data collection } \\
\text { approach }\end{array}$} & \multirow[t]{2}{*}{ Key findings } & \multirow{2}{*}{$\begin{array}{c}\text { Connolly } \\
\text { et al. } \\
\text { scale } \\
\text { score }\end{array}$} \\
\hline & & & & & & \\
\hline $\begin{array}{l}\text { Hollett and Ehret } \\
\text { (2017) }\end{array}$ & $\begin{array}{l}\text { How civic youth } \\
\text { can engage in } \\
\text { a youth-driven } \\
\text { program - Metro: } \\
\text { Building Blocks } \\
\text { (MBB), provided } \\
\text { within a digital } \\
\text { media learning } \\
\text { lab in an urban } \\
\text { public library. }\end{array}$ & $\begin{array}{l}\text { Participants played } \\
\text { together on the } \\
\text { same server and } \\
\text { location (the } \\
\text { learning lab) where } \\
\text { the budding city } \\
\text { planners built } \\
\text { components of } \\
\text { Metro, sometimes } \\
\text { joining from } \\
\text { home if unable to } \\
\text { physically attend. }\end{array}$ & $3(12-16)$ & $\begin{array}{l}\text { The analysis was } \\
\text { illustrated upon } \\
\text { observation, and video } \\
\text { recordings of nearly } \\
90 \text { hours of gameplay } \\
\text { as well as field notes } \\
\text { and interviews with } \\
\text { participants. }\end{array}$ & $\begin{array}{l}\text { - Collaboration } \\
\text { and engagement } \\
\text { were observed. The } \\
\text { engagement was } \\
\text { desire-driven toward } \\
\text { collaborative transit } \\
\text { station, more than } \\
\text { interest-driven. } \\
\text { - Back-and-forth } \\
\text { movements between } \\
\text { one player and the } \\
\text { others took place, } \\
\text { assisting them then } \\
\text { leaving them to work } \\
\text { independently. } \\
\text { • The analytical interest } \\
\text { of this paper focused } \\
\text { on three rhythmic } \\
\text { elements: pulsation; } \\
\text { reciprocation; and } \\
\text { oscillation. } \\
\text { - This study is useful } \\
\text { for considering } \\
\text { how to program } \\
\text { designers, mentors } \\
\text { and educators can } \\
\text { encourage productive } \\
\text { participation. } \\
\text { • Limitations of } \\
\text { the game/study - all } \\
\text { participants were male. }\end{array}$ & 7 \\
\hline Hong-An (2016) & $\begin{array}{l}\text { Exploring the } \\
\text { use of values } \\
\text { generated by } \\
\text { prosumers } \\
\text { through their } \\
\text { production in } \\
\text { affinity spaces. }\end{array}$ & $\begin{array}{l}\text { No intervention } \\
\text { reported, as } \\
\text { researchers aimed } \\
\text { at analysing } 25 \\
\text { discussion threads. }\end{array}$ & $\mathrm{N} / \mathrm{D}(\mathrm{N} / \mathrm{D})$ & $\begin{array}{l}\text { Content analysing } \\
\text { methods was used } \\
\text { to investigate } \\
\text { the descriptions, } \\
\text { discussions, and } \\
\text { artefacts produced } \\
\text { on MC affinity space } \\
\text { regarding MC. }\end{array}$ & $\begin{array}{l}\text { - Threads gave players } \\
\text { opportunities to } \\
\text { exchange news, legal } \\
\text { and technical changes } \\
\text { to be able to access } \\
\text { the game; sharing a } \\
\text { narrative or visual } \\
\text { experience of MC and } \\
\text { giving opinions and } \\
\text { suggestions that can } \\
\text { offer the game cultural } \\
\text { and social gaming } \\
\text { exchanges. These } \\
\text { threads can be used as } \\
\text { self-directed learning } \\
\text { and as educational and } \\
\text { motivational support } \\
\text { for others, as well } \\
\text { as an entry point for } \\
\text { socialization. }\end{array}$ & 6 \\
\hline Hook et al. (2016) & $\begin{array}{l}\text { Examining } \\
\text { the influence } \\
\text { of evaluative } \\
\text { social identity } \\
\text { on brand-based } \\
\text { social network } \\
\text { commitment. }\end{array}$ & $\begin{array}{l}\text { No intervention } \\
\text { was reported. }\end{array}$ & $394(6-14)$ & $\begin{array}{l}\text { Measurements were: } \\
\text { Evaluative Social } \\
\text { Identity; Negative } \\
\text { Anticipated Emotions; } \\
\text { Positive Anticipated } \\
\text { Emotions; Community } \\
\text { Commitment and } \\
\text { Recommendations; } \\
\text { Personal Self-esteem; } \\
\text { Perceived Behavioural } \\
\text { Control. }\end{array}$ & $\begin{array}{l}\text { - Evaluative social } \\
\text { identity and network } \\
\text { recommendations are } \\
\text { positively associated, } \\
\text { where a higher level } \\
\text { of evaluative social } \\
\text { identity leads to a } \\
\text { higher level of network } \\
\text { commitment. } \\
\text { - Children with high } \\
\text { evaluative social } \\
\text { identity showed positive } \\
\text { feelings and emotions } \\
\text { when they were able to } \\
\text { interact with the brand- } \\
\text { based social network, } \\
\text { leading children to } \\
\text { network commitment } \\
\text { and network } \\
\text { recommendations. } \\
\text { They felt negative } \\
\text { emotions when they } \\
\text { were prevented from } \\
\text { connecting to the } \\
\text { brand-based social } \\
\text { network. }\end{array}$ & 12 \\
\hline
\end{tabular}


International Journal of Game-Based Learning

Volume 11 • Issue 4 • October-December 2021

Table 2. Continued

\begin{tabular}{|c|c|c|c|c|c|c|}
\hline \multirow{2}{*}{$\begin{array}{l}\text { Author/ } \\
\text { citation }\end{array}$} & \multirow[t]{2}{*}{ Study aim } & \multirow{2}{*}{$\begin{array}{l}\text { Research design } \\
\text { (intervention) }\end{array}$} & \multirow{2}{*}{$\begin{array}{c}\text { Sample } \\
\mathrm{N} \text { (Age) }\end{array}$} & \multirow{2}{*}{$\begin{array}{l}\text { Data collection } \\
\text { approach }\end{array}$} & \multirow[t]{2}{*}{ Key findings } & \multirow{2}{*}{$\begin{array}{c}\text { Connolly } \\
\text { et al. } \\
\text { scale } \\
\text { score }\end{array}$} \\
\hline & & & & & & \\
\hline $\begin{array}{l}\text { (MacCormack \& } \\
\text { Freeman, 2019) }\end{array}$ & $\begin{array}{l}\text { To describes a } \\
\text { pilot study for } \\
\text { a play-based } \\
\text { intervention } \\
\text { designed to } \\
\text { support the } \\
\text { development } \\
\text { of social } \\
\text { competence of } \\
\text { youths with ASD } \\
\text { using Minecraft. }\end{array}$ & $\begin{array}{l}\text { Youth with ASD } \\
\text { participated } 8 \\
\text { 1-hr sessions in } \\
\text { free (no roles or } \\
\text { objectives) and } \\
\text { structured (role- } \\
\text { based objective) } \\
\text { play in MC during } \\
81 \text {-hr sessions } \\
\text { with a typically } \\
\text { developing peer } \\
\text { and two adults with } \\
\text { video modelling, } \\
\text { adult facilitation, } \\
\text { and mediation. }\end{array}$ & $\begin{array}{l}4 \text { ASD }+1 \\
\text { TD }(11-13) \\
\& 2 \text { Adults }\end{array}$ & $\begin{array}{l}\text { Researchers use video } \\
\text { recordings of in-person } \\
\text { and in-game play to } \\
\text { score the quality of } \\
\text { social play, measured by } \\
\text { rates of initiations and } \\
\text { level of engagement and } \\
\text { affect. }\end{array}$ & $\begin{array}{l}\text { - Although a low } \\
\text { degree of motivation } \\
\text { of youth with ASD to } \\
\text { interact with others was } \\
\text { observed during the } \\
\text { free play in the early } \\
\text { sessions, structured play } \\
\text { increases the quality of } \\
\text { social play and players } \\
\text { were more engaged } \\
\text { as they participate in } \\
\text { shared goals as they had } \\
\text { to make and respond to } \\
\text { social bids. } \\
\text { - Players' social play } \\
\text { through the early } \\
\text { sessions was identified } \\
\text { to be more parallel } \\
\text { and associative, but } \\
\text { the play became often } \\
\text { cooperative during the } \\
\text { later sessions. } \\
\text { - The result of this } \\
\text { intervention suggests } \\
\text { that as the players } \\
\text { practiced making } \\
\text { social initiations during } \\
\text { structured play, they } \\
\text { transferred the skills to } \\
\text { free play. } \\
\text { 'The present } \\
\text { study suggests that } \\
\text { videogame play may } \\
\text { be a useful modality } \\
\text { for programs by which } \\
\text { youth with ASD can } \\
\text { learn and practice social } \\
\text { skills through play' } \\
\text { (p. } 234 \text { ). }\end{array}$ & 10 \\
\hline $\begin{array}{l}\text { Mavoa, Carter, } \\
\text { and Gibbs (2018) }\end{array}$ & $\begin{array}{l}\text { Examining } \\
\text { engagement with } \\
\text { MC for children } \\
\text { aged 3-12 living } \\
\text { in Melbourne. }\end{array}$ & $\begin{array}{l}\text { No intervention } \\
\text { was reported. }\end{array}$ & $\begin{array}{l}753 \\
\text { (children= } \\
3-12 ; \\
\text { parents }= \\
36-45)\end{array}$ & $\begin{array}{l}\text { A questionnaire } \\
\text { filled by parents to } \\
\text { collect data about the } \\
\text { children's demographic } \\
\text { information, general } \\
\text { digital gameplay, } \\
\text { Minecraft gameplay, } \\
\text { YouTube use, general } \\
\text { 'screen time' and } \\
\text { finally basic parents' } \\
\text { demographic questions. }\end{array}$ & $\begin{array}{l}\text { - Almost } 50 \% \text { of } \\
\text { children had played } \\
\text { MC in the month prior } \\
\text { to filling the survey. } \\
\text { Older children are more } \\
\text { likely to play MC than } \\
\text { younger; boys in the } \\
\text { youngest group } 3-5 \text { play } \\
\text { MC } 3 \text { to } 5 \text { time more } \\
\text { than girls; but older } \\
\text { group 9-12, girls play } \\
\text { MC more than boys } \\
\text { (they drop off from } 72 \% \\
\text { of all boys at } 9-11 \text { years } \\
\text { old to } 54 \% \text { of boys aged } \\
11-12 \text { years old); } 46 \% \\
\text { of parents reported } \\
\text { that children start play } \\
\text { MC at age } 6 \text { or } 7 \text { years } \\
\text { old; a lot of children } \\
\text { play less than one hour } \\
\text { a day; children play } \\
\text { MC in single player } \\
\text { mode play more often; } \\
\text { most children play in } \\
\text { creative mode; and } \\
37 \% \text { of children watch } \\
\text { YouTube related to MC. }\end{array}$ & 13 \\
\hline
\end{tabular}


International Journal of Game-Based Learning

Volume 11 •Issue 4 • October-December 2021

Table 2. Continued

\begin{tabular}{|c|c|c|c|c|c|c|}
\hline \multirow{2}{*}{$\begin{array}{l}\text { Author/ } \\
\text { citation }\end{array}$} & \multirow[t]{2}{*}{ Study aim } & \multirow{2}{*}{$\begin{array}{l}\text { Research design } \\
\text { (intervention) }\end{array}$} & \multirow{2}{*}{$\begin{array}{l}\text { Sample } \\
\mathrm{N} \text { (Age) }\end{array}$} & \multirow{2}{*}{$\begin{array}{l}\text { Data collection } \\
\text { approach }\end{array}$} & \multirow[t]{2}{*}{ Key findings } & \multirow{2}{*}{$\begin{array}{c}\text { Connolly } \\
\text { et al. } \\
\text { scale } \\
\text { score }\end{array}$} \\
\hline & & & & & & \\
\hline $\begin{array}{l}\text { Nebel et al. } \\
\text { (2016a) }\end{array}$ & $\begin{array}{l}\text { Finding out } \\
\text { if social } \\
\text { competition } \\
\text { increases } \\
\text { cognitive load, } \\
\text { engagement, } \\
\text { interest, and } \\
\text { subsequently } \\
\text { learning. }\end{array}$ & $\begin{array}{l}\text { Researchers built } \\
\text { one world for } \\
\text { each of the four } \\
\text { groups. They } \\
\text { created a learning } \\
\text { task, tested the } \\
\text { environment and } \\
\text { gave participants a } \\
\text { tutorial for the task. }\end{array}$ & $115(18-42)$ & $\begin{array}{l}\text { A pre-survey and post- } \\
\text { survey for cognitive load } \\
\text { measurement, revised } \\
\text { the User Engagement } \\
\text { Scale, the Situational } \\
\text { Interest, and completed } \\
\text { the Game Experience } \\
\text { Questionnaire. }\end{array}$ & $\begin{array}{l}\text { - The extraneous } \\
\text { load was reported by } \\
\text { players in the social } \\
\text { competition due to the } \\
\text { increase in effort in } \\
\text { working with the group, } \\
\text { but no differences in } \\
\text { satisfaction could be } \\
\text { observed. } \\
\text { - A higher number of } \\
\text { competitors decreased } \\
\text { some engagement } \\
\text { because distracting } \\
\text { each other, but higher } \\
\text { challenges were } \\
\text { positively related to } \\
\text { the better level of } \\
\text { engagement. } \\
\text { - Players in the } \\
\text { competitive scenarios } \\
\text { learned significantly } \\
\text { less. }\end{array}$ & 12 \\
\hline $\begin{array}{l}\text { Nebel, Schneider, } \\
\text { Beege, et al. } \\
(2017)^{*}\end{array}$ & $\begin{array}{l}\text { To evaluate } \\
\text { the level of } \\
\text { cooperation on } \\
\text { learning, play, } \\
\text { cognitive load, } \\
\text { efficiency, and } \\
\text { play experience. }\end{array}$ & $\begin{array}{l}\text { Participants } \\
\text { were divided } \\
\text { randomly into two } \\
\text { groups: voluntary } \\
\text { cooperation (VC) } \\
\text { and increased task } \\
\text { interdependence } \\
\text { (ITI) where } \\
\text { collaboration was } \\
\text { necessary to solve } \\
\text { the task. }\end{array}$ & $56(15-20)$ & $\begin{array}{l}\text { A survey about the } \\
\text { experience and pattern } \\
\text { of playing of MC. Texts } \\
\text { were analysed according } \\
\text { to the task criteria and } \\
\text { speaking time. Cognitive } \\
\text { Load was used, and } \\
\text { standardized learning } \\
\text { measurements were used } \\
\text { as learning performance } \\
\text { indicators. }\end{array}$ & $\begin{array}{l}\text { - MC offers players } \\
\text { more opportunities for } \\
\text { creativity, and they } \\
\text { were pleasant, and only } \\
\text { positive feedback was } \\
\text { yielded. } \\
\text { - Students' group task } \\
\text { performance increased } \\
\text { as they were required } \\
\text { to collaborate, so } \\
\text { individual learning } \\
\text { outcomes increased } \\
\text { as their interaction } \\
\text { increased. Cognitive } \\
\text { load was not affected } \\
\text { by the collaboration } \\
\text { requirement, but } \\
\text { collaboration was used } \\
\text { to enable learning, } \\
\text { and more mental } \\
\text { effort was invested } \\
\text { by the ITI group due } \\
\text { to the cooperative } \\
\text { requirement. } \\
\text { - Limitations of the } \\
\text { game - some players } \\
\text { lose their attention } \\
\text { easily and do their own } \\
\text { gaming, delaying the } \\
\text { process of the given } \\
\text { task. }\end{array}$ & 12 \\
\hline $\begin{array}{l}\text { Niemeyer and } \\
\text { Gerber (2015) }\end{array}$ & $\begin{array}{l}\text { Exploring the } \\
\text { phenomena of } \\
\text { digital maker } \\
\text { culture by } \\
\text { examining five } \\
\text { MC channels on } \\
\text { YouTube. }\end{array}$ & $\begin{array}{l}\text { No intervention } \\
\text { was reported. }\end{array}$ & 1 (N/D) & $\begin{array}{l}\text { Researchers interviewed } \\
\text { an avid player about best } \\
\text { channels for MC maker } \\
\text { culture, subscribed to } 5 \text {, } \\
\text { reviewed } 10 \text { videos from } \\
\text { each channel, and then } \\
\text { analysed comments. }\end{array}$ & $\begin{array}{l}\text { - All videos provided } \\
\text { something to the } \\
\text { viewer, such as how } \\
\text { to complete a task or } \\
\text { build something; some } \\
\text { players expressed their } \\
\text { own experience of } \\
\text { creating something. } \\
\text { - Creators and viewers } \\
\text { engaged in lengthy } \\
\text { discussions. } \\
\text { - Creators showed a } \\
\text { high quality of MC } \\
\text { knowledge and video } \\
\text { production. } \\
\text { - Limitations - lack of } \\
\text { information about the } \\
\text { reviewed channels. }\end{array}$ & 8 \\
\hline
\end{tabular}


International Journal of Game-Based Learning

Volume 11 • Issue 4 • October-December 2021

Table 2. Continued

\begin{tabular}{|c|c|c|c|c|c|c|}
\hline \multirow[t]{2}{*}{$\begin{array}{l}\text { Author/ } \\
\text { citation }\end{array}$} & \multirow[t]{2}{*}{ Study aim } & \multirow[t]{2}{*}{$\begin{array}{l}\text { Research design } \\
\text { (intervention) }\end{array}$} & \multirow{2}{*}{$\begin{array}{l}\text { Sample } \\
\mathbf{N} \text { (Age) }\end{array}$} & \multirow[t]{2}{*}{$\begin{array}{l}\text { Data collection } \\
\text { approach }\end{array}$} & \multirow[t]{2}{*}{ Key findings } & \multirow{2}{*}{$\begin{array}{l}\text { Connolly } \\
\text { et al. } \\
\text { scale } \\
\text { score }\end{array}$} \\
\hline & & & & & & \\
\hline Potts (2015) & $\begin{array}{l}\text { Exploring the } \\
\text { impact of MC } \\
\text { popular players } \\
\text { on the language } \\
\text { and interactions } \\
\text { of the fan } \\
\text { community. }\end{array}$ & $\begin{array}{l}\text { No intervention } \\
\text { was reported. }\end{array}$ & $1(30)$ & $\begin{array}{l}\text { Three data collection } \\
\text { sources used: } 63 \\
\text { YouTube videos, } \\
\text { comments on these } \\
\text { videos, and an interview } \\
\text { with one of the famous } \\
\text { YouTube channels } \\
\text { producer in the UK. }\end{array}$ & $\begin{array}{l}\text { - Sexual innuendo } \\
\text { was the most frequent } \\
\text { themes using a different } \\
\text { linguistic tactic. } \\
\text { References to romantic } \\
\text { acts and feelings in } \\
\text { a relationship were } \\
\text { also observed, at male } \\
\text { gaming partners. } \\
\text { - Highest frequent } \\
\text { sexual themes in } \\
\text { comments were } \\
\text { whether they were gay } \\
\text { or straight, masculine or } \\
\text { feminine. } \\
\text { - The anonymity } \\
\text { offered by MC allows } \\
\text { players to blur and } \\
\text { utilize their characters, } \\
\text { which can be used to } \\
\text { promote social justice } \\
\text { and offer a transgressive } \\
\text { engagement in the } \\
\text { digital world. }\end{array}$ & 7 \\
\hline $\begin{array}{l}\text { Sanz-Martos, } \\
\text { Martínez- } \\
\text { Martínez, and } \\
\text { Creus (2018) }\end{array}$ & $\begin{array}{l}\text { To analyse } \\
\text { users' behaviour, } \\
\text { the amount } \\
\text { and content of } \\
\text { messages and } \\
\text { compare the } \\
\text { structures and } \\
\text { workings of MC } \\
\text { and League of } \\
\text { Legends (LOL) }\end{array}$ & $\begin{array}{l}\text { No intervention } \\
\text { was reported. }\end{array}$ & $\mathrm{N} / \mathrm{D}(\mathrm{N} / \mathrm{D})$ & $\begin{array}{l}\text { Content analysing } \\
\text { methods used of } \\
\text { messages of two famous } \\
\text { YouTube channels }\end{array}$ & $\begin{array}{l}\text { - There is different } \\
\text { behaviour depending } \\
\text { on the communication } \\
\text { space. Mundo-MC } \\
\text { community recognise } \\
\text { each other and even } \\
\text { inform others if one } \\
\text { planned to be absent } \\
\text { for a while; conversely } \\
\text { to YouTube where } \\
\text { participation follow } \\
\text { any user, and it is } \\
\text { not necessary to be } \\
\text { subscribed to the } \\
\text { channel. } \\
\text { - The interest in the } \\
\text { topic remains as it } \\
\text { is. Members of the } \\
\text { community tend to be } \\
\text { grouped into teams of } \\
\text { acquaintances. They } \\
\text { find the game's form is } \\
\text { a place for exchanges } \\
\text { of messages and } \\
\text { information. } \\
\text { - Although the } \\
\text { number of viewers } \\
\text { and the unorganized } \\
\text { arrangement of the } \\
\text { comments prevents } \\
\text { the establishment of } \\
\text { a community, there } \\
\text { was enough evidence } \\
\text { that users shared and } \\
\text { exchanged knowledge, } \\
\text { and they undoubtedly } \\
\text { learn. }\end{array}$ & 6 \\
\hline $\begin{array}{l}\text { Schneier and } \\
\text { Taylor (2018) }\end{array}$ & $\begin{array}{l}\text { To examine the } \\
\text { collaborative } \\
\text { engagement of } \\
\text { MC players. }\end{array}$ & $\begin{array}{l}\text { Participants were } \\
\text { divided into groups } \\
\text { and allowed to play } \\
\text { MC Pocket Edition } \\
\text { for 30-60 minutes. }\end{array}$ & $\begin{array}{l}10(\text { Avg. } \\
16, S D= \\
10.88)\end{array}$ & $\begin{array}{l}\text { participatory } \\
\text { observation of both on- } \\
\text { and off-screen activity } \\
\text { for participants playing } \\
\text { MC to discuss players' } \\
\text { engagements with MC. }\end{array}$ & $\begin{array}{l}\text { - Players remained } \\
\text { active in the game, but } \\
\text { their bodies positioning } \\
\text { was largely consistent } \\
\text { through the play, same } \\
\text { seated positions facing } \\
\text { screens. } \\
\text { - All players engaged } \\
\text { with each other in the } \\
\text { play sessions with } \\
\text { MC PE and social and } \\
\text { emotional interactions } \\
\text { were observed. }\end{array}$ & 9 \\
\hline
\end{tabular}


Table 2. Continued

\begin{tabular}{|c|c|c|c|c|c|c|}
\hline \multirow{2}{*}{$\begin{array}{l}\text { Author/ } \\
\text { citation }\end{array}$} & \multirow[t]{2}{*}{ Study aim } & \multirow{2}{*}{$\begin{array}{l}\text { Research design } \\
\text { (intervention) }\end{array}$} & \multirow{2}{*}{$\frac{\text { Sample }}{\mathrm{N} \text { (Age) }}$} & \multirow{2}{*}{$\begin{array}{l}\text { Data collection } \\
\text { approach }\end{array}$} & \multirow[t]{2}{*}{ Key findings } & \multirow{2}{*}{$\begin{array}{l}\text { Connolly } \\
\text { et al. } \\
\text { scale } \\
\text { score }\end{array}$} \\
\hline & & & & & & \\
\hline $\begin{array}{l}\text { Stone, Mills, and } \\
\text { Saggers (2019). }\end{array}$ & $\begin{array}{l}\text { To report on } \\
\text { the support for } \\
\text { social interactions } \\
\text { received by three } \\
\text { students with } \\
\text { ASD through } \\
\text { Minecraft }\end{array}$ & $\begin{array}{l}\text { No intervention } \\
\text { was reported. }\end{array}$ & $3(9-10)$ & $\begin{array}{l}\text { Data collected through } \\
\text { screen observations } \\
\text { of children playing } \\
\text { Minecraft and semi- } \\
\text { structured interviews }\end{array}$ & $\begin{array}{l}\text { - MC provide } \\
\text { platforms for students } \\
\text { to engage in reciprocal } \\
\text { conversations. } \\
\text { Attracting others' } \\
\text { attention, communicate } \\
\text { and engage with others } \\
\text { physical and in the } \\
\text { virtual worlds was } \\
\text { observed. } \\
\text { - Playing MC with } \\
\text { others provides } \\
\text { opportunities for } \\
\text { social interactions } \\
\text { in multimodal ways } \\
\text { that are not available } \\
\text { in face-to-face and } \\
\text { offline contexts. The } \\
\text { game could be used to } \\
\text { promote children's with } \\
\text { ASD ability to initiate } \\
\text { and sustain social } \\
\text { interactions in inclusive } \\
\text { educational settings. }\end{array}$ & 10 \\
\hline Willett (2018) & $\begin{array}{l}\text { Understanding } \\
\text { the ways social } \\
\text { aspects of } \\
\text { consuming media } \\
\text { contribute to } \\
\text { meaning-making } \\
\text { practices. }\end{array}$ & $\begin{array}{l}\text { No intervention } \\
\text { was reported. }\end{array}$ & $6(8-9)$ & $\begin{array}{l}\text { Semi-structured } \\
\text { interviews with children, } \\
\text { and one with parents } \\
\text { about participants' } \\
\text { understandings of } \\
\text { online games and } \\
\text { gaming resources and } \\
\text { sociocultural influences } \\
\text { of online games. }\end{array}$ & $\begin{array}{l}\text { - Children showed a } \\
\text { general understanding } \\
\text { of the gaming industry, } \\
\text { due to their investments } \\
\text { in membership, } \\
\text { Realms, merchandise } \\
\text { of games. They were } \\
\text { aware of numerous } \\
\text { revenue-generating } \\
\text { mechanisms and learn } \\
\text { about financial aspects } \\
\text { including critical } \\
\text { evaluation of the } \\
\text { games' income through } \\
\text { social resources, such } \\
\text { as older siblings, } \\
\text { friends and parents. } \\
\text { Socio-economic and } \\
\text { cultural contexts of } \\
\text { families and parental } \\
\text { interests affect online } \\
\text { gaming's influence } \\
\text { on children's media } \\
\text { literacy skills. } \\
\text { - Limitations of the } \\
\text { study: the sample size } \\
\text { is small. }\end{array}$ & 8 \\
\hline
\end{tabular}

${ }^{*}$ Academic and motivation for learning is a secondary outcome for these studies.

than younger; indeed, $46 \%$ of parents reported that children start play Minecraft at age six or seven years old. Willett (2018) investigated the social aspects of 'consuming media' from six children aged eight to nine and reported that the children exhibited a general understanding of the gaming industry due to their investments in memberships, realms, and the merchandise of games. Furthermore, Sexual content has been discussed by Potts (2015), whose research analysed videos posted by Minecraft players on YouTube and reported that the number of sexual references or innuendos was very high; references to sex or gender relationships mostly involved sexual innuendo, sexual activity, and nudity. Therefore, it is crucial to investigate the impact of the game on teenager players and their personal privacy and safety, and what measures could be taken to prevent inappropriate sexual content.

Addiction and health concerns were addressed in previous research, and parents and teachers seemed to be able to prevent these limitations by planning the activity. For example, Smolčec and Smolčec (2014) stated that they had a concern about addiction, where players may spend so much time playing the game that it could reduce time spent in developing their physical or social skills and improving their general knowledge. However, the researchers stated that they witnessed their son 
crafting and doing things that were useful in Minecraft, and this led to positive outcomes in language and collaboration skills. Furthermore, about a quarter of non-players in Callaghan's study (2016) were concerned about game addiction and time-wasting. However, the teacher and researcher did not see any time wasted during the lesson; in fact, the teacher reported that by using MinecraftEdu students became more productive, engaged, and willing to complete desired tasks. Players were interested in launching their work in MinecraftEdu immediately upon entering the classroom (Callaghan, 2016). Moreover, Schneier and Taylor (2018) reported that although players remained active within the game environment, their bodies positioning was mostly consistent through the play, same seated positions facing screens, which may raise a concern regarding their physical health. Further research is encouraged to investigate Minecraft addiction and whether it has an impact on physical or mental health.

In summary of the concern, Minecraft attracts the attention of students from different demographic backgrounds and stimulates learning. It allows them to work towards the accomplishment of their goals. However, it is impossible to state definitively whether Minecraft is a good or bad influence because its efficacy should be considered based on the context of where and how it is used. From one point of view, there is a level of risk in playing Minecraft. However, risks exist everywhere, such as attendance at school, in online material, and in schoolbooks, so teaching children to be safe is always necessary, regardless of the educational methods teachers use. In general, Minecraft can facilitate communication and interaction between the learner players and learning content.

The reviewed studies have some limitations and weaknesses that are imperative to understand because it encourages further areas of research. This critique does not reduce the value of these articles, but it will highlight factors that teachers and school leaders need to be aware of because these might affect the generalisability of some of these articles. The most observable limitation is the lack of experimental studies, where in fact only eight of the reviewed studies include a control group. Studies with a control group are needed because they will allow readers to see the outcomes when these variables are eliminated and isolated. Furthermore, some articles lack detail on the research design. For example, Elliott (2014) used Minecraft in a classroom to develop a curriculum, but the research mentioned only one student. Readers might question the impact of the game on other students and whether the game changed the whole classroom environment or impacted only the reported student. Another example is where Blanco-Herrera et al. (2019) did not include details how long the intervention lasted, and details on what the participants were asked to do. Morover, some research lacks information about the participants (e.g., Bebbington \& Vellino, 2015; Cilauro, 2015; Dezuanni et al., 2015; Schneier \& Taylor, 2018) while other research has missing information about the project (e.g., Dezuanni et al., 2015). This missing information is vital for reusing the criteria in another setting. Furthermore, some research (e.g., Sáez-López et al., 2015) was conducted in two different countries. Although this might be counted as an advantage, researchers did not explain whether there was a difference between the performance of the two groups, as the game and the intervention might be understood differently due to cultural differences. It would be preferable for further research to examine the cultural value of using Minecraft for educational purposes. Moreover, Cilauro (2015) did not state whether the participants that day had performed similarly to or differently from each other, nor what kind of libraries the participants had built by the end of that day. Another example would be the research conducted by Cipollone et al. (2014), where the authors did not clearly describe the results: researchers thought that full implementation of the intervention was prevented. Further research is encouraged to translate the observation notes to statements, helping readers to learn the outcomes of the intervention more easily. Overall, it is paramount that the results section is clear and covers all the mentioned elements, regardless of the outcomes. None of the articles in this review mentioned whether there was a difference between playing Minecraft as a multiplayer or a single-player game although previous systematic reviews of digital games, in general, reported that playing a multiplayer computer game had more of an effect on students' learning (Clark et al., 2015). There has been no study on whether it is different playing together in one place or playing 
together at a distance. This information might be helpful, especially for teaching online programs and offering online support for learners.

Some of the reviewed studies have issues related to sampling. For example, Wernholm and Vigmo (2015) had a sample of three children, but the researchers did not give a clear description of the participants, such as their gender, age, school grade, or level of expertise in the game. It is not clear whether the players were already friends. This information might be imperative because all the previously mentioned factors could affect the implementation of Minecraft. This could be an advantage because the participants' information matters for future researchers who want to apply the intervention in their classroom. Another issue was the number of participants in the research. Most of the research embraced either a very small number of participants (Elliott, 2014; Ellison, 2017; Potts, 2015; Marlatt, 2018a, 2018b, Smolčec \& Smolčec, 2014; Swier, 2014; Wernholm \& Vigmo, 2015; Willett, 2018), did not mention their age (Cilauro, 2015), or had a gender bias (Hollett \& Ehret, 2017). For example, Bebbington and Vellino (2015) interviewed eight participants, but only one was female. Overall, a sample issue does not signify an entirely negative aspect of the research, but it might affect its generalisation because the situation might be different when applying the game to a larger number of students in a classroom.

In summary of the reviewed papers' limitations, due to the previously mentioned weaknesses and limitations, further research is needed in order to provide parents, teachers, and school leaders with effective strategies to improve the use of Minecraft in the classroom. More research is needed to investigate parents' perspectives on the game and their possible involvement in further interventions. There is a need for further research to examine the short-term and long-term outcomes of Minecraft in the classroom for students' future life skills. An appropriate age is another critical area that teachers need to consider before implementing Minecraft in the classroom. Overall, a suitable environment is essential for the successful implementation of Minecraft, which is strongly suggested in order to improve the learning and knowledge of students.

\section{IMPLICATIONS AND CONCLUSION}

Minecraft is a unique, open-world game that can be successfully implemented in classrooms for educational purposes. It offers opportunity for creating activities of interest that encourage learners to be creative with no restrictions or boundaries for its us, giving unlimited creative potential. Minecraft's advantage is that it is an accessible, creative game teachers can modify and adjust its use as they choose, and when done well can be very productive for learning. This review examined all of the available empirical data on Minecraft use for learning. These studies reviewed included application of the game in the classrooms or in design of a curriculum to be used in lessons or activities. Most of the studies reviewed found that Minecraft is useful for teaching and enhances students' social and academic skills. Previous research was reviewed based on their primary target of social skills for educational use. Some studies aimed to improve students' knowledge of specific academic skills.

Based on the results of the papers reviewed here, teachers are encouraged to use Minecraft as an educational tool and to follow children's interests in its implementation to engage students' motivation for learning. This may be especially helpful for children with learning disabilities or with autism with restricted interests that can be accommodate in the game (Gunn \& Delafield-Butt, 2016). To overcome unexpected events, educators are also advised to learn how to play the game before implementing it in the classroom to avoid unexpected problems. Further, teachers could ask students to collaborate in an academic activity, which would help them to develop social skills. Finally, teachers interested in implementing Minecraft in their school or learning environment could establish a private server and involve students to support their needs and interests. Children with particular or special needs may benefit from participating in the planning. This game could be implemented as an additional activity for students, which would make learning more enjoyable. It should be clear that it's not Minecraft that benefits academic learning and social engagement, but it how it has been designed and maintain 
to deliver lessons. Through the game, educators can walk students through various steps in social interaction and academic learning and can identify areas that need improvement. Nonetheless, although further research is necessary to clarify the issue, the studies reported here demonstrate overwhelmingly positive outcomes of using Minecraft in the classroom. Thus, teachers and parents are encouraged to play the game with their students or their children in informed and constructive ways, keeping the freedom of self-directed play in learning to the foreground. Positive outcomes include, but are not limited to, the motivation for engagement in learning and social and academic skill improvements. The Minecraft world enables learners' 'zest for learning' (Whitehead, 1929) with its open-world, creative and cooperative gameplay format, allowing the creation of projects and stories that enable learning, and the co-creation or sharing of these with others - a cornerstone of education, whether in learning to work with each other socially or in the technical knowledge of facts and logical operations.

This systematic review has several limitations. First, it was limited to research published in English, which excluded unpublished studies or studies in other languages. Second, a large percentage of studies in the area were excluded because they were conference abstracts or proceedings papers. Thus, several relevant papers might have been excluded; selection and publication bias are acknowledged. Third, the review was limited to Minecraft and did not include other, similar digital games that might be relevant for children's academic and social performance; therefore, the outcomes are limited to Minecraft. Altogether, these limitations may have influenced the results, discussion, and recommendations made in this review. Despite these limitations, the benefits of Minecraft in education to enhance social skills and academic learning outweigh the potential disadvantages. All evidence in the studies reviewed here indicates that Minecraft's use in classrooms and public places were helpful in developing players' social skills: evidence of sharing, communication, monitoring, having a sense of social responsibility, collaborating and cooperating with others was explicitly noted. On the other hand, some limitations were reported, such as age-appropriateness, time management in using Minecraft in classrooms, and students' attraction to the desired goal. These limitations and disadvantages tended to arise as a result of inadequate preparation, unclear purpose, or a lack of knowledge of Minecraft. For future implementation, teachers are recommended to look closely at how Minecraft can be employed to fulfil their students' interests and age-appropriate level of learning. Researchers are encouraged to test the long-term impact of Minecraft on learning academic and social skills. 
International Journal of Game-Based Learning

Volume $11 \cdot$ Issue $4 \cdot$ October-December 2021

\section{REFERENCES}

Abdul Jabbar, A. I., \& Felicia, P. (2015). Gameplay engagement and learning in game-based learning: A systematic review. Review of Educational Research, 85(4), 740-779. doi:10.3102/0034654315577210

Al-Washmi, R., Bana, J., Knight, I., Benson, E., Kerr, O. A. A., Blanchfield, P., \& Hopkins, G. (2014, October). Design of a Math learning game using a Minecraft Mod. In ECGBL2014-8th European Conference on Games Based Learning: ECGBL2014 (p. 10). Academic Conferences and Publishing International.

Baek, Y., \& Touati, A. (2017). Exploring how individual traits influence enjoyment in a mobile learning game. Computers in Human Behavior, 69, 347-357. doi:10.1016/j.chb.2016.12.053

Baldwin, J. (1894; 1906). Mental development in the child and the race (2nd ed.). New York: Macmillan Company.

Bebbington, S., \& Vellino, A. (2015). Can playing Minecraft improve teenagers' information literacy? Journal of Information Literacy, 9(2), 6-26. doi:10.11645/9.2.2029

Blanco-Herrera, J. A., Gentile, D. A., \& Rokkum, J. N. (2019). Video Games can Increase Creativity, but with Caveats. Creativity Research Journal, 31(2), 119-131. doi:10.1080/10400419.2019.1594524

Boyle, E. A., Connolly, T. M., Hainey, T., \& Boyle, J. M. (2012). Engagement in digital entertainment games: A systematic review. Computers in Human Behavior, 28(3), 771-780. doi:10.1016/j.chb.2011.11.020

Butler, J. O. (2017). Mindcrafting: The Semantic Characteristics of Spontaneous Names Generated as an Aid to Cognitive Mapping and Navigation of Simulated Environments. Simulation \& Gaming, 48(5), 588-602. doi: $10.1177 / 1046878117712750$

Callaghan, N. (2016). Investigating the role of Minecraft in educational learning environments. Educational Media International, 53(4), 244-260. doi:10.1080/09523987.2016.1254877

Checa-Romero, M., \& Pascual Gómez, I. (2018). Minecraft and machinima in action: Development of creativity in the classroom. Technology, Pedagogy and Education, 27(5), 625-637. doi:10.1080/1475939X.2018.1537933

Choo, A., Karamnejad, M., \& May, A. (2013). Maintaining long distance togetherness synchronous communication with Minecraft and Skype. In 2013 IEEE International Games Innovation Conference (pp. 27-35). doi:10.1109/IGIC.2013.6659138

Cilauro, R. (2015). Community building through a public library Minecraft Gaming Day. The Australian Library Journal, 64(2), 87-93. doi:10.1080/00049670.2015.1015209

Cipollone, M., Schifter, C. C., \& Moffat, R. A. (2014). Minecraft as a creative tool: A case study. International Journal of Game-Based Learning, 4(2), 1-14. doi:10.4018/ijgbl.2014040101

Clark, D. B., Tanner-Smith, E. E., \& Killingsworth, S. S. (2015). Digital games, design, and learning a systematic review and meta-analysis. Review of Educational Research. PMID:26937054

Clemenson, G. D., Henningfield, C. M., \& Stark, C. (2019). Improving hippocampal memory through the experience of a rich Minecraft environment. Frontiers in Behavioral Neuroscience, 57, 1-13. doi:10.3389/ fnbeh.2019.00057 PMID:30949036

Connolly, T. M., Boyle, E. A., MacArthur, E., Hainey, T., \& Boyle, J. M. (2012). A systematic literature review of empirical evidence on computer games and serious games. Computers \& Education, 59(2), 661-686. doi:10.1016/j.compedu.2012.03.004

Craft, J. (2016). Rebuilding an empire with Minecraft: Bringing the classics into the digital space. The Classical Journal, 111(3), 347-364. doi:10.5184/classicalj.111.3.0347

Davis, K., Boss, J. A., \& Meas, P. (2018). Playing in the Virtual Sandbox: Students' Collaborative Practices in Minecraft. International Journal of Game-Based Learning, 8(3), 56-76. doi:10.4018/IJGBL.2018070104

De Jaegher, H., Perakyla, A., \& Stevanovic, M. (2016). The co-creation of meaningful action: bridging enaction and interactional sociology. Philosophical Transactions of the Royal Society of London. Series B: Biological Sciences, 371(1693). 10.1098/rstb.2015.0378 
Delafield-Butt, J. (2018). The Emotional and Embodied Nature of Human Understanding: Sharing narratives of meaning. In C. Trevarthen, J. Delafield-Butt, \& A.-W. Dunlop (Eds.), The Child's Curriculum: Working with the natural voices of young children. Oxford University Press.

Delafield-Butt, J. T., \& Adie, J. (2016). The Embodied Narrative Nature of Learning: Nurture in school. Mind, Brain and Education : the Official Journal of the International Mind, Brain, and Education Society, 10(2), 14.

Delafield-Butt, J. T., \& Gangopadhyay, N. (2013). Sensorimotor intentionality: The origins of intentionality in prospective agent action. Developmental Review, 33(4), 399-425.

Dezuanni, M., O'Mara, J., \& Beavis, C. (2015). "Redstone is like electricity”: Children's performative representations in and around "Minecraft". E-Learning and Digital Media, 12(2), 147-163. doi:10.1177/2042753014568176

Donaldson, M. (1978). Children's Minds. Harper Collins.

Education Scotland. (2016). Curriculum for Excellence: Technologies principles and practice. Retrieved 26 July 2018, from https://education.gov.scot/Documents/Technologies-es-os.pdf

Egbert, J., \& Borysenko, N. (2019). Standards, engagement, and Minecraft: Optimizing experiences in language teacher education. Teaching and Teacher Education, 85, 115-124. doi:10.1016/j.tate.2019.06.015

Egenfeldt-Nielsen, S., Smith, J., \& Tosca, S. (2013). Understanding video games (2nd ed.). Routledge. doi: $10.4324 / 9780203116777$

Ejsing-Duun, S., \& Skovbjerg, H. M. (2016). Copycat or Creative Innovator? Reproduction as a Pedagogical Strategy in Schools. Electronic Journal of E-learning, 14(2), 83-93.

Elliott, D. (2014). Levelling the playing field: Engaging disadvantaged students through game-based pedagogy. Australian Journal of Language and Literacy, 37(2), 34-40.

Ellison, T. (2017). Digital Participation, Agency, and Choice: An African American Youth's Digital Storytelling about Minecraft. Journal of Adolescent \& Adult Literacy, 61(1), 25-35. doi:10.1002/jaal.645

Felicia, P. (2009). Digital games in schools a handbook for teachers. Belgium: European Schoolnet. Retrieved 15 July 2016, from http://games.eun.org/upload/gis_handbook_en.pdf

Frönes, I. (2007). On theories of dialogue, self and society Redefining socialization and the acquisition. On Being Moved: From Mirror Neurons to Empathy, 201-217.

Gameplay. (n.d.). Retrieved January 08, 2016, from http://minecraft.gamepedia.com/Gameplay

Gauquier, E., \& Schneider, J. (2013). Minecraft programs in the library. Young Adult Library Services, 11(2), $17-19$.

Gee, J. (2013). Good video games and good learning (2nd ed.). Peter Lang Publishing Inc.

Gee, J. P. (2017). Teaching, learning, literacy in our high-risk high-tech world: A framework for becoming human. Teachers College Press.

Grossard, C., Grynspan, O., Serrette, S., Jouen, A. L., Bailly, K., \& Cohen, D. (2017). Serious games to teach social interactions and emotions to individuals with autism spectrum disorders (ASD). Computers \& Education, 113, 195-211. doi:10.1016/j.compedu.2017.05.002

Gtaking5. (2010, January 10). Minecraft. Retrieved January 28, 2016, from https://gamefaqs.gamespot.com/ boards/995185-minecraft/56535079?page $=1$

Gunn, K. C., \& Delafield-Butt, J. T. (2016). Teaching children with autism spectrum disorder with restricted interests: A review of evidence for best practice. Review of Educational Research, 86(2), 408-430. doi: $10.3102 / 0034654315604027$

Halverson, R. (2012). Afterword: Games and the Future of Education Research. In Games, learning, and society: Learning and meaning in the digital age (1st ed., pp. 433-446). Cambridge University Press.

Hill, V. (2015). Digital citizenship through game design in Minecraft. New Library World, 116(7/8), 369-382. doi:10.1108/NLW-09-2014-0112 
International Journal of Game-Based Learning

Volume $11 \cdot$ Issue $4 \cdot$ October-December 2021

Hollett, T., \& Ehret, C. (2017). Civic rhythms in an informal, media-rich learning program. Learning, Media and Technology, 42(4), 483-499. doi:10.1080/17439884.2016.1182926

Hong-An, W. (2016). Video game prosumers: Case study of a Minecraft affinity space. Visual Arts Research, 42(1), 22-37. doi:10.5406/visuartsrese.42.1.0022

Hook, M., Baxter, S., \& Kulczynski, A. (2016). Children's participation in brand-based social networks: Examining the role of evaluative social identity, self-esteem and anticipated emotions on commitment and desire to recommend. International Journal of Consumer Studies, 40(5), 552-561. doi:10.1111/ijcs.12300

iTunes. (n.d.). Minecraft: Pocket Edition. Retrieved January 27, 2016, from https://itunes.apple.com/gb/app/ minecraft-pocket-edition/id479516143?mt=8

Janine, T. P. (2018). How gaming, artificial intelligence and big data is changing education. Journal of Game, Game Art, and Gamification, 2(2).

Lutz, S., \& Huitt, W. (2004). Connecting cognitive development and constructivism: Implications from theory for instruction and assessment. Constructivism in the Human Sciences, 9(1), 67-90.

MacCormack, J., \& Freeman, J. (2019). Part 2: The virtual environment social program for youths with autism spectrum disorder. International Journal of Play Therapy, 28(4), 218.

Marcon, N., \& Faulkner, J. (2016). Exploring Minecraft as a pedagogy to motivate girls' literacy practices in the secondary English classroom. Engineers Australia, 51(1), 63.

Marlatt, R. (2018a). Literary analysis using Minecraft: An Asian American youth crafts her literacy identity. Journal of Adolescent \& Adult Literacy, 62(1), 55-66.

Marshall, C., \& Rossman, G. B. (1999). The "what" of the study: Building the conceptual framework. Designing Qualitative Research, 3, 21-54.

Mason, J. H. (2017). The value of creativity: The origins and emergence of a modern belief. Routledge.

Mavoa, J., Carter, M., \& Gibbs, M. (2017, October). Beyond addiction: positive and negative parent perceptions of Minecraft play. In Proceedings of the Annual Symposium on Computer-Human Interaction in Play (pp. 171181). ACM.

Mavoa, J., Carter, M., \& Gibbs, M. (2017). Children and Minecraft: A survey of children's digital play. New Media \& Society, 20(9), 3283-3303. doi:10.1177/1461444817745320

McColgan, M., Colesante, R., \& Andrade, A. (2018). Pre-Service Teachers Learn to Teach with Serious Games. Journal of STEM Education, 19(2), 19-25.

Mekler, E. D., Bopp, J. A., Tuch, A. N., \& Opwis, K. (2014, April). A systematic review of quantitative studies on the enjoyment of digital entertainment games. In Proceedings of the 32nd annual ACM conference on Human factors in computing systems (pp. 927-936). ACM.

Minecraft. (n.d.). Retrieved July 03, 2019, from https://www.minecraft.net/en-us/store/

Moffat, D. C., Crombie, W., \& Shabalina, O. (2017). Some video games can increase the player's creativity. International Journal of Game-Based Learning, 7(2), 35-46.

Moher, D., Liberati, A., Tetzlaff, J., \& Altman, D. G. (2009). Preferred reporting items for systematic reviews and meta-analyses: The PRISMA statement. Annals of Internal Medicine, 151(4), 264-269.

Mojang Support. (n.d.). Where can I buy Minecraft? Retrieved January 08, 2016, from https://help.mojang.com/ customer/en/portal/articles/325947-where-can-i-buy-minecraft-

Nebel, S., Schneider, S., Beege, M., Kolda, F., Mackiewicz, V., \& Rey, G. D. (2017a). You cannot do this alone! Increasing task interdependence in cooperative educational videogames to encourage collaboration. Educational Technology Research and Development, 65(4), 993-1014.

Nebel, S., Schneider, S., \& Rey, G. D. (2016). From duels to classroom competition: Social competition and learning in educational videogames within different group sizes. Computers in Human Behavior, 55, 384-398. 
Nebel, S., Schneider, S., Schledjewski, J., \& Rey, G. D. (2017b). Goal-Setting in educational video Games: Comparing goal-setting theory and the goal-free effect. Simulation \& Gaming, 48(1), 98-130.

Newzoo.com. (2014, March 25). Analyzing game franchises: Why gamers love Minecraft. Retrieved January 08, 2016, from https://newzoo.com/insights/articles/analyzing-game-franchises-gamers-love-minecraft/

Niemeyer, D. J., \& Gerber, H. R. (2015). Maker culture and Minecraft: Implications for the future of learning. Educational Media International, 52(3), 216-226. doi:10.1080/09523987.2015.1075103

Ozmon, H., \& Craver, S. (2008). Philosophical foundations of education. Pearson/Merrill Prentice Hall.

PEGI. (2016). Pan European Game Information - Advanced Search. Pegi.info. Retrieved 26 September 2016, from https://pegi.info/search-pegi?q=Minecraft\&op=Search\&filter-age\%5B\%5D=\&filterdescriptor $\% 5 \mathrm{~B} \% 5 \mathrm{D}=\&$ filter-publisher $=\&$ filter-platform $\% 5 \mathrm{~B} \% 5 \mathrm{D}=\&$ filter-release-year $\% 5 \mathrm{~B} \% 5 \mathrm{D}=\&$ -

page=1\&form_build_id=form-LtU7hP1FqtKKrjmtuJm4-BAqHZO1FxcO2ESS2x4xoGg\&form_id=pegi_ search_form

Petry, A. (2018). Playing in Minecraft: An exploratory study 1. Revista FAMECOS, 25(1), 1-18. doi:10.15448/1980-3729.2018.1.27156

Piaget, J. (1953). The Origin of Intelligence in the Child. Routledge \& Paul.

Piaget, J. (1962). Play, dreams and imitation in childhood. Routledge \& Kegan Paul.

Potts, A. (2015). 'Love you guys (no homo)' How gamers and fans play with sexuality, gender, and Minecraft on YouTube. Critical Discourse Studies, 12(2), 163-186. doi:10.1080/17405904.2014.974635

Quiring, T. (2015). From voxel vistas: Place-making in Minecraft. Journal of Virtual Worlds Research, 8(1), 1-17.

Reese, H. W. (2011). The learning-by-doing principle. Behavioral Development Bulletin, 17(1), 1.

Sáez-López, J. M., Miller, J., Vázquez-Cano, E., \& Domínguez-Garrido, M. C. (2015). Exploring application, attitudes and integration of video games: MinecraftEdu in middle school. Journal of Educational Technology \& Society, 18(3), 114-128.

Saito, D., Washizaki, H., \& Fukazawa, Y. (2017). Comparison of Text-Based and Visual-Based Programming Input Methods for First-Time Learners. Journal of Information Technology Education, 16, 209-226.

Sanz-Martos, S., Martínez-Martínez, S., \& Creus, A. (2018). Talking about games: Gamers' digital communication spaces as the object of study. Catalan Journal of Communication \& Cultural Studies, 10(2), 231-245. doi:10.1386/ cjcs.10.2.231_1

Schneier, J., \& Taylor, N. (2018). Handcrafted gameworlds: Space-time biases in mobile Minecraft play. New Media \& Society, 20(9), 3420-3436. doi:10.1177/1461444817749517

Short, D. (2012). Teaching scientific concepts using a virtual world-Minecraft. Teaching Science, 58(3), 55-58.

Smolčec, M., \& Smolčec, F. (2014). Using Minecraft for learning English. TESL-EJ, 18(2), 1-15.

Squire, K. (2011). Video Games and Learning: Teaching and Participatory Culture in the Digital Age. Technology, Education-Connections (the TEC Series). Teachers College Press.

Stone, B. G., Mills, K. A., \& Saggers, B. (2019). Online multiplayer games for the social interactions of children with autism spectrum disorder: A resource for inclusive education. International Journal of Inclusive Education, 23(2), 209-228.

Swier, R. (2014). Tasks for Easily Modifiable Virtual Environments. The JALT CALL Journal, 10(3), 203-219.

Teaching with MinecraftEdu. (n.d.). Retrieved January 28, 2016, from http://services.minecraftedu.com/wiki/ Teaching_with_MinecraftEdu

Tobias, S., \& Fletcher, D. (2012). Learning from computer games: A research review. In Serious games: The challenge (pp. 6-17). Springer.

Tong, S. (2011, August 28). Mining data from Minecraft. Retrieved January 08, 2016, from https://www.gamespot. com/articles/mining-data-from-minecraft/1100-6331569/ 
Trevarthen, C., \& Delafield-Butt, J. (2013). Biology of shared experience and language development: regulations for the inter-subjective life of narratives. The infant mind: Origins of the social brain, 167-199.

Trevarthen, C., \& Delafield-Butt, J. (2014). The Infant's Creative Vitality, In Projects of Self-Discovery and Shared Meaning: How They Anticipate School, and Make It Fruitful. In S. Robson \& S. F. Quinn (Eds.), The Routledge International Handbook of Young Children's Thinking and Understanding (pp. 3-18). Routledge.

Vygotsky, L. (1978). The Role of Play in Development. In Mind in society: The development of higher mental process (pp. 92-104). Harvard University Press.

Vygotsky, L. (1986). Thought and Language (A. Kozulin, Trans.). Harvard University Press.

Wardlow, L. (2014). The Philosophies of Learning Behind Improving Access to Learning Resources. Pearson Research and Innovation Network. Retrieved 20 July 2016, from https://www.pearsoned.com/wp-content/uploads/ DigitalAge_AccessReport_021714.pdf

Wendel, V., Gutjahr, M., Battenberg, P., Ness, R., Fahnenschreiber, S., Goebel, S., \& Steinmetz, R. (2013). Designing a collaborative serious game for team building using Minecraft. In P. Escudeiro \& C. V. DeCarvalho (Eds.), Proceedings of the 7th European Conference on Games Based Learning (vols. 1-2, pp. 569-578). Academic Press.

Wernholm, M., \& Vigmo, S. (2015). Capturing children's knowledge-making dialogues in Minecraft. International Journal of Research \& Method in Education, 38(3), 230-246.

Whitehead, A. N. (1929). The Aims of Education and Other Essays. Macmillan Company.

Whitehead, A. N. (1933). Adventures of Ideas. Macmillan.

Willett, R. (2018). 'Microsoft bought Minecraft... who knows what's going to happen?!': A sociocultural analysis of 8-9-year-olds' understanding of commercial online gaming industries. Learning, Media and Technology, $43(1), 101-116$.

Willett, R. J. (2015). The discursive construction of "good parenting' and digital media - the case of children's virtual world games. Media Culture \& Society, 37(7), 1060-1075. doi:10.1177/0163443715591666 